\title{
CLASE, PODER Y PRIVILEGIO EN LA SOCIEDAD CORPORATIVA *
}

\author{
Salvador Giner \\ Brunel University, Londres
}

\section{INTRODUCCION}

El presente ensayo versa sobre algunos aspectos de la desigualdad y del conflicto social en el roundo de hoy. Su enfoque es histórico, pues la forma y dirección del proceso de desigualdad en nuestro mundo no se explican sin una comprensión de su sociogénesis y de la transición al universo hoy emergente. Este se analiza aquí en términos de lo que, con la debida cautela, puede recibir el nombre de sociedad corporativa. Por lo tanto lo que sigue contiene unas reflexiones sobre la clase, la jerarquía, el poder y el privilegio (y sus conflictos) en las sociedades corporativas.

La industrialización, el capitalismo, el parlamentarismo y otros factores comunes han conferido un modesto, aunque significativo, grado de semejanza a varias sociedades occidentales. Sin ignorar que existen decisivas diferencias estructurales y culturales entre ellas, ello permite planteat el asunto con una cierta y tentativa generalidad. No obstante y para tes-

* Este ensayo explora con mayor detalle algunos de los problemas que, junto a mi coautor, tuve Ia oportunidad de apuntar brevemente en ciertos pasajes de La sociedad corporativa (S. Giner y M. Pérez Yxuela, 1979, pp. 53-64), así como en otros textos. Para evitar teiteraciones reproduzco con la máxima economía solamente aquellas nociones que, pese a no ser inéditas, son necesarias para el entendimiento de la argumentacion. Una version anterior de la mayor parte de este ensayo fue publicada en Comentario Sociológico 1981, Madrid: CECA. La presente contiene mejoras, correcciones y algunas nuevas puntualizaciones. 
tringir mi margen de error, mis observaciones se refieren más a la Europa del Noroeste y a Norteamérica que a la meridional y sólo to hacen, indirectamente, a la deI Este y a la Unión Soviética. ${ }^{1}$

No poseemos aún una teoría general satisfactoria de la desigualdad en el mundo moderno, aunque exista un número de intentos al respecto. ${ }^{2}$ Las reflexiones que siguen sufren de esta ausencia pero se benefician de tales intentos y se sitúan en su matco. A la vista de sus tesultados y de los míos propios, es menester subrayar que estas notas deben ser entendidas sólo como modesto y provisional ejercicio de esclarecimiento teórico.

\section{LOS DESNIVELES DE LA DESIGUALDAD $Y$ SU MUDANZA MODERNA}

\subsection{El desnivel social y su reducción relativa}

La desigualdad social ha sufrido cambios notables bajo las fuerzas que han dado lugar al mundo moderno. Algunos de ellos han afectado al espectro total de desigualdad, es decir, a la distancia o desnivel que separa a quienes ocupan las posiciones más altas de aquellos que ocupan las más bajas, así como en muchos casos a las distancias particulares entre rangos intermedios. Otros cambios han afectado a la naturaleza misma de la desigualdad; ciertas formas de subordinación, mando, deferencia, autoridad y control han sido erosionadas profundamente, mientras que han surgido otras nuevas. Ambos fenómenos -cambios en distancia y cambios en especie- están íntimamente relacionados entre sí y quizá puedan ser entendidos mejor como facetas de una única y compleja mudanza histórica. Sólo pueden separarse analíticamente. Me atendré, para empezar, a la cuestión del desnivel social.

La distancia que separa a ricos de pobres, podetosos de humildes, dirigentes de dirigidos es un fenómeno histórico. Varía según la comunidad, asociación o configuración social a la que pertenecen las gentes. Varía también en grado y alcance según la naturaleza de la sociedad entera. La dimensión general, societaria, de la desigualdad, su longitud, distancia o

1. Para la Europa meridional, véase S. Ginet, 1982 (b). Para España, no existe ningún estudio general de la corporatización; no obstante, es importante la tesis doctoral de Eduardo Moyano (1982), que analiza la situacion en Ia agricultura. También el de Juan Linz sobre grupos políticos de interés (1981).

2. Por ejemplo, K. Davies y W. Moore (1966), G. Lenski (1966), pp. 1.116 y 434446 , y H. Strasser (1980). 
trecho total en una sociedad compleja dada difiere de la que se encuentra en cualquier otra sociedad. Así, la distancia que un día separaba al déspota oriental del labrador más pobre era mucho mayor que la que separa hoy a este último del moderno soberano o presidente del Estado. La naturaleza misma de la separación era diferente, puesto que los emperadores orientales eran dioses para el pueblo: todo parecía indicar su divinidad, sus poderes sobrenaturales, su inefable gloria. En este sentido, aunque quizá no en otros, puede suponerse que la desigualdad en las antiguas civilizaciones eta mayor que en ciertos países del mundo moderno. Ello parece ser cierto aún en las peores fases de la industrialización y la proletarización. Aunque admitiéramos que el más humilde de los proletarios en una hilatura de Lancashire, en el siglo $\mathrm{xIx}$, no estaba en mejor situación que un labrador desheredado trabajando en régimen de corvée para el faraón, tendríamos también que admitit que durante siglos, milenios quizá, la posición del segundo apenas cambió, mientras que la del primero 0 , más precisamente, la de sus hijos y descendientes, sí lo hizo. Aunque estos continuaton perteneciendo a las clases subordinadas, adquirieron un número de derechos políticos y económicos citcunscritos peto significativos, una participación en servicios públicos anteriormente inexistentes y ciertas garantías para su libertad civil. Ulteriores comparaciones entre clases históricas (más que entre personas en posiciones jerátquicas distintas y por lo tanto menos comparables) mostrarían cómo es cierto que el advenimiento de los tiempos modernos trajo consigo mudanzas sustan. ciales en el ámbito de la desigualdad social.

Una de ellas ha sido la relativa reducción en el desnivel de la desigualdad, el alcance total social entre los extremos de poder, autotidad, privilegio y propiedad, aunque ello haya ocurrido sólo a to largo de ciertos ejes (por lo tanto no se afirma, por ejemplo, que la desigualdad de ingresos entre el millonario y el peón agrícola sea hoy menor que la que otrora separaba al señor de la tierra y a su vasallo sin ella: quizá sea mayor en muchos casos). Tal teducción no ha sido homogénea ni simple. Al contrario: como espero mostrar, la disminución de la desigualdad en algunos ámbitos de la vida ha reforzado su permanencia en otros, y hasta ha hecho posible su aumento en algunos sentidos. Ya Tocqueville, al observar la sociedad norteamericana, avisó de que el igualitarismo podía convertirse en el soporte de formas nuevas de desigualdad. Es más, el proceso asimétrico en la zeducción de la desigualdad que ha tenido lugar en las sociedades occidentales en algunos campos no tiene por qué continuar indefinidamente. No hay pruebas de que, en virtud de alguna futura revolución, se rompran para siempre las barreras que quedan de discriminación, exclusión y apropiación de bienes y valores por parte 
de unos a expensas de los demás. La noción de que se ha producido una teducción progresiva (aunque azarosa) del desnivel total de la desigual. dad tal como existía en el mundo premoderno es, no obstante, cosa di. ferente, y parece encajar con los hechos conocidos (aunque no encaje con ciertas teotías influyentes sobre las clases y su conflicto, tal como aún nos son presentadas). Es una noción, además, que es perfectamente compatible con la posibilidad de que surjan entre nosotros nuevas formas de desigualdad.

Ha sido la confuencia de varios procesos históricos modernos lo que ha producido la relativa reducción en el desnivel de la desigualdad tradicional. Tales procesos podrian agruparse en cuatro grandes corrientes analíticamente aislables: la producción de un excedente económico superior a la capacidad de las clases dominantes para su consumo, derroche o almacenamiento; el desarrollo de un sistema económico mundial; el auge de una ciudadanía ligada al Estado y la legitimación e institucionalización de la innovación en algunos terrenos. Sus respectivos efectos sobre la desigualdad podrían resumirse aś:

a) Los efectos socioestructurales del excedente económico industrial. Gerhard Lenski ${ }^{3}$ ha propuesto una hipótesis en este campo que merece reproducirse en escorzo. Según él, «la aparición de sociedades industriales maduras señala la primera inversión signiffcativa en la muy antigua tetn. dencia evolutiva hacia un aumento permanente de la desigualdad». Señales de que dectinan las desigualdades pueden hallarse en la tendencia hacia la inclusión de amplias partes de la población en el proceso político, una más amplia distribución de los ingresos y mayor participación en el bienestar, aunque no deba ignorarse la presencia de la desigualdad en otros terrenos. La explicación de esta invetsión sin precedentes en la tendencia histótica se apoya sobte el hecho de que «la técnica en particular y la cultura en general» se han hecho tan complejas que "quienes están en posición de mando no pueden ya comprender las funciones de sus subordinados». Son, por lo tanto, «amos de una proporción menor de lo que necesitan saber para el control efectivo sobre sus subordinados». $Y$, «en la medida en que delegan su autoridad o se fían de los mecanis. mos del mercado, facilitan la difusión del poder y el privilegion. Esta inversión estriba también en otro fenómeno, relacionado sin duda con el aumento y difusión del conocimiento técrico: la magnitud del aumento en productividad. Aquí Lenski acude a lo que yo llamaría una teoría de rebose o derratme de la reducción en el desnivel de la desigualdad (a ese

3. G. Lenski (1966), pp. 308-318, 434-434-441, para las citas que siguen. 
mismo desnivel, él lo llama «grado de desigualdad»): las clases dominantes modernas y sus élites pueden ya por fin «hacer concesiones económicas en términos relativos sin sufrir necesariamente pérdida alguna en términos absolutos» en su posición de privilegio y poder. Si la tasa de crecimiento es lo bastante alta, la élite y la clase dominante pueden hacer concesiones sin dejat de continuar consiguiendo ganancias absolutas. La faita de apropiación de todo el excedente económico halla su eco en la falta de control de todo el poder político, como ocurre con la nueva ideología democrática, la cual «afirma que el Estado es propiedad colectiva del pueblo».

A despecho de un númeto de cualificaciones (por ejemplo, la descripción que Lenski hace de la historia de la desigualdad puede parecer demasiado lineal), su razonamiento sobre las causas del declive en el grado de desigualdad parece cuerdo, aunque no vaya acompañado de una consideración de la aparición de nuevas desigualdades. Las pruebas históricas muestran con creces que la desviación del excedente hacia lo suntuoso y lo ceremonial y la acaparación y almacenamiento de riquezas por parte de una minoría ha sido la norma en todo el civilizado pretérito de nuestra raza (es obvio que en sociedades "prehistóricas» o «primitivas» prevalecían otros criterios para la acumulación, la apropiación y la distribución de la riqueza). Cuando, en tiempos pretéritos, se producía alguna redis. tribución, como fue el caso de los subsidios imperiales de grano y circo para la plebe tomana, se evitaba cuidadosamente cualquier reducción en Las pautas de desigualdad existentes. ${ }^{4}$ Tan solo el crecimiento exponencial moderno de bienes manufacturados ha producido efectos igualitarios relativos sobre la generalidad de la población. Efectos a tener en cuenta, sin duda, en cualquier valoración de la llamada ley de Pareto sobre la distribución de la riqueza. Según elia, la curva del reparto de las riquezas varía muy poco de una a otra época en uno o vatios países, y ello con independencia de su régimen político y económico. No obstante, y a la luz de las conocidas curvas de Lorenz, ciertos economistas han concluido que la desigualdad de ingresos, tras impuestos pagados, suele diferir entre los países en relación indirecta a su grado de industrialización. A mayor industrialización mayor grado de igualdad..$^{5}$ Esto corregitía la aplicación

4. P. Veyne (1976).

5. Curvas de Lorenz medidas según coeficientes de Gini. De todas formas, ciertas situaciones revolucionarias (¿efímetas?) pueden producit excepciones; ciertos observa* dores afirmaban (años anteriores a I973) que China (sociedad pre y semuindustrial a la sazón) presentaba la distribución de ingresos tnás igual, inferior quizás a una razón de $4 / 1$ en los diferenciales salariales. Una vez más, ello ignora relaciones de poder e ideología, lo cual es grave, si se considera la fase de la «revolución cultural» maoísta 
de la ley o curva de Pareto, relegando su validez al mundo preindustrial (y semiindustrial) y abonaría la tesis aquí expuesta, ya que la reducción en desigualdad (económica, que no política) se postula únicamente a partir del momento en que se dispara la productividad y se produce el derrame antedicho, el cual sólo puede tener lugar bajo condiciones industriales.

Aceptemos pues por el momento que en las sociedades industriales avanzadas se ha producido un declive incipiente en ciertas formas de desigualdad, sin pérdida notable en el grado absoluto de bienestar y recursos de las clases dominantes. Quizá se haya producido alguna pérdida en su poder político y cultural y en su goce del privilegio a causa del ascenso de otros grupos, como los compuestos por sindicalistas, técnicos, profesionales, políticos y tecnócratas. Con ventaja para ellos, éstos han podido incorporarse en el nuevo sistema distributivo de bienes y recursos, sobre todo en virtud de las concesiones que ellos y sus predecesores consiguieron extraer de las clases dominantes: son las condiciones de la nueva situación alta productividad, abundancia, protección legal de la oposición política- las que han posibilitado tal ascenso. Mas hay también otros factores en la reducción de la desigualdad que no pueden reducirse sin más a un entendimiento puramente mecánico de las consecuencias del modo industrial de producción, es decir, de la alta productividad y el derrame de riquezas. Así, debe contemplatse seriamente la posibilidad de que la presencia duradera de varios movimientos radicales, teformistas y socialistas en varios países occidentales haya producido efectos igualitarios significativos sobre sus propias sociedades. Parece que no faltan pruebas empíricas de que ello haya sido asi. ${ }^{\circ}$ Aceptar esto no es concluir que el capitalismo avanzado, teñido de socialdemoctacia, haya mudado de por sí la naturaleza misma de la desigualdad de ingresos de modo sustancial. Sí es, en cambio, comprender mejor esa desigualdad tal como aparece en nuestros días, incorporando en ella aspectos políti.

de la época. Aparte de los diversos trabajos que confirman la validez de la ley y curva de Pareto, véanse los de Binet y Meade poniéndola en tela de juicio para las fases más recientes, con industrialización avanzada.

6. C. Hewitt (1977), apoyándose en datos, afirma, contra la opinión acađémica prevalente, que la democracia política y los partidos socialistas democráticos han producido efectos positivos en la reducción de la desigualdad. El argumento cortiente es que es el desarrollo económico, y no el socialismo, to que constituye la única causa relevante. Por razones contrapuestas, tanto los funcionalistas como los marxistas apoyan la opinión «sofisticada». Kolko, por ejemplo, afirma que el welfare capitalism sno ha cambiado la naturaleza de Ia desigualdad de ingresos ni ha elevado el nivel de vida de las clases con menores ingresos por encima del que hubiera alcanzado si no hubieran sufrido la presión de los impuestos federales (en los EE. UU.)». G. Kolko (1962), p. 39. 
cos que son ajenos a la lógica estricta del capitalismo. Es curioso, dicho sea de paso, que el fenómeno de la disminución de la desigualdad bajo condiciones de reformismo político sea ignorado tanto por sectores signiflcativos de la derecha como de la izquierda, y ello por tazones ideológicas opuestas.

b) La internacionalización de la desigualdad a través del sistema ecanómico mundial. Como explicó Marx, uno de los efectos principales de capitalismo, tanto del mercantil como del industrial, es la creación de un mercado mundial. La interdependencia económica, señaló, signiftca el establecimiento de relaciones de clase no sólo entre los estratos dominantes y los subordinados en los países metropolitanos, y entre tales estratos y los pueblos coloniales, sino, más significativamente, entre las clases trabajadoras de los centros industriales imperiales y las de las colonias. Esta relación debe ser incorporada a nuestro análisis para mejorar y corregir la teoría de Ia inversión propuesta por Lenski, la cual debe ser vista en el más amplio marco del sistema económico mundial. ${ }^{7}$

Con toda posibilidad los teóricos del sistema mundial exageran hoy el grado en que existe una integración general en un único sistema capitalista, ya que a menudo incluyen páses con «socialismo» de Estado, en los que los criterios para la creación, consumo y distribución de riqueza no son los de mercado. Sus conclusiones, suponiendo que no sean erróneas para un futuro, son por lo menos prematuras. Ello no obstante, sí es cierto que las estructuras de desigualdad social son en gran medida transnacionales y que el sistema económico en el que están imbricadas también lo es. Ha ocurrido algo más que un mero desplazamiento de la pobreza hacia la periferia de los focos industriales hegemónicos. $\mathrm{Ha}$ surgido una verdadera mundiatización de la desigualdad y ello a un doble nivel: entre países (ricos/pobres; poderosos/subordinaclos) y dentro de ellos (creación de pautas internas de dominación dependientes de las transnacionales). Aunque estos fenómenos tienen viejos antecedentes históricos (las burguesías compradoras y las clases dominantes dominadas no son nada nuevo), es su consolidación a escala mundial lo que constituye un rasgo sin precedentes.

El sistema taundial emergente ha favorecido la erosión de ciertos extremos de desiguaidad en sus centros begemónicos, en los que la acumulación de riqueza y recursos ha hecho posible el reformismo social. En Occidente la mitigación de la pobreza y la penuria pública sin que se haya producido una redistribución radical de la riqueza ha dependido de ondas

7. R. Rubinson (1976). 
largas de prosperidad. Si bien setía erróneo identificar el alivio de la destitución y la miseria mediante la política social de los gobiernos con la reducción de la desigualdad, existen relaciones interesantes entre ambas cosas. En lo que tespecta al desarrollo del sistema económico mundial habrá que concluir que, en virtud de la acumulación desigual de la riqueza a favor de los países dominantes, dicha política (que incluye la tributación progresiva de los ingresos altos) ha coadyuvado a disminuir el desnivel global de desigualdad sin por ello dejar de mantener y hasta fomentar el desnivel transnacional, aumentando así el contraste entre sociedades enteras. Existen precedentes históricos notorios. Así, la introducción de la esclavitud intercontinental en los impexios marítimos eutopeos tuvo, a escala menor, efectos semejantes. Mas ni en aquel entonces las sociedades proveedoras de mano de obra esclava estaban en condiciones de oponerse a ello, ni el sistema mundial era tan vasto.

Las cosas, sin embargo, son mucho más complicadas. Ni Occidente es el foco único de la desigualdad, ni la relación entre centro y petiferia es monovalente. Es, como mínimo, ambivalente. Occidente es también la civilización que ha generado el igualitarismo como ideología y la deslegitimación de órdenes sociales preindustriales (feudales, sultánicos, despóticos) cuyas pautas de desigualdad eran más inhumanas y amplias que las suyas propias. Además, Ja incipiente reducción de la desigualdad en los centros avanzados no puede ser entendida como predicción de tendencias futuras: la desindustrialización, el desempleo creciente, la tecesión econórnica y las ya mencionadas formas nuevas de desigualdad podrían parar las tendencias hacia la disminución de la desigualdad, o crear diffcultades serias en su progreso. Por otra patte, en algunas partes de la periferia quizá se puedan invertir las tendencias actuales hacia la desigualdad, tal como otrora ocutriera en el centro, ya a través de la revolución política, ya por medio de una industrialización autóctona. Algunos ejemplos, sobre todo en el Este de Asia, abonan esta última posibilidad.

c) Ciudadanía y clase social. La disolución de la sociedad feudal tardía y su expresión política, el Ständestaat, abrió el camino a la reestructuración de la desigualdad en términos de clase social y, en mucho menor grado al principio, también de ocupación. Ello ocurrió en el marco del Estado moderno y fue posibilitado por él. Lejos de set una institución hostil a la movilidad social y la igualdad, el estado modemo fue, desde su nacimiento, parte esencial del nuevo orden. Creció como institución cuya función era, entre otras, proteger a los ciudadanos que estaban en condiciones de medrat bajo la nueva economía competitiva capitalista, y 
lograr más propiedades, privilegio y poder. El acceso diferencial a estos codiciados bienes quedó garantizado mediante criterios bien diferentes de Ios prevalentes en la sociadad anterior. Es significativo que esos criterios incluyen - para confusión de algunos observadores-- el autodesvanecimiento aparente del propio Eistado que sostenía el nuevo orden en cuestión. Tales criterios se basaban (y aún lo hacen hoy en día) en una concepción jurídicamente universalista de la igualdad: igualdad ante la ley, acceso igual al voto. ${ }^{8}$ Por su parte, el etbor mucho más radical de la igualdad de oportunidades hizo su aparición efectiva sólo en su estado postetior de la modernidad, aunque bajo las fuerzas que había desatado la misma lógica de la ciudadania.

Aunque arraigada en la noción de la soberanía de leyes abstractas y generales —el moderno sistema legal-_-9 el nuevo orden permitía y hasta fomentaba una especie de desigualdad: la clasista. La desigualdad de clase no entrañaba solamente la estructuración de la sociedad entera según las líneas de este nuevo colectivo social -la clase-, sino también la formación de otros grupos clave, unidos a él de modo sutil. Uno de los más señalados era el de las asociaciones mercantiles, industriałes y profesionales dotadas de las caractetísticas de la persona jurídica (corporaciones) y no obstante carentes de responsabilidades personales, es decir, morales. Igualmente ligada al nuevo orden clasista fue la aparición de una «clase» política, constituida por las élites de la autoridad y el poder procedentes de las diferentes clases sociales con participación legítima en la politeya, así como la de sus movimientos sociales y grupos de interés. El ámbito de participación legítina, antes restringido a la bourgeoisie conquérante y a los miembros embourgeoisés de la nobleza terrateniente, se había abierto poco a poco (o abruptamente en algunos países) hasta abrazar prácticamente a cualquier sector de interés en cualquier clase, si bien la participación política real de cada uno seguía siendo cuestión de grado y peso diferentes.

La ciudadanía, pues, es un fenómeno ambivalente. Por una parte permite la continuación de la desigualdad de clase y su reptoducción. Las clases potentes pueden colonizar tanto la rama ejecutiva como la administrativa del Estado en una medida suficiente para que los asuntos pú-

8. T. H. Marshall (1950). En contraste con Marshall mi ensayo enfatiza la interdependencia entre clase y la ciudadania, que no son vistas aquí como contrarios. Para Marshaill las fuerzas de la igualdad (ciudadania) se oponen a las de la desigualdad (clase).

9. «Sisterna legal» en el sentido de Unger, distinto de la ley consuetudinatia y de la burocrática. Unger muestra cómo no pueđe ser entendido como mera excrecencia de Ia burguesía. R. M. Unger (1976), pp. 52-53. 
blicos sean conducidos de acuerdo con sus intereses y ello sin violar en absoluto sus principios universalistas. La ciudadanía es un medio generalizado para la creación de aquellas formas de privilegio que son congruentes con ella. Por otra parte, en una sociedad civilizada la ciudadanía es, como institución, fuente de libertad, privacidad y, claro está, de igualdad. Puede ser invocada y usada por los movimientos sociales igualitarios (las minorías étnicas, las mujeres) e invocada para la enmienda de distribuciones injustas de ingresos y recursos. La lógica del industrialismo posee también esta ambivalencia y por lo tanto no sólo es paraleta a ella sino que refuerza las dos tendencias divergentes de la ciudadanía. Así, las necesidades de la economía moderna, basada en la tecnología, exigen un plantel muy amplio para el reclutamiento de talento y pericia. Este es suministrado por el círculo siempre creciente de la ciudadanía. $Y$ ésta es quizá la razón por la cual la extensión de los derechos civiles y las tasas de movilidad ascendente en las sociedades industriales avanzadas pueden considerarse como íntimamente ligadas entre sí. ${ }^{10}$ En contraste con ello, la misma lógica funciona en dirección opuesta: los diferenciales salariales, los incentivos antiigualitarios, las recompensas de status, todos ellos continúan como estímulos necesarios para la actividad humana. Es más, las recompensas e incentivos que los beneficiados pueden hacer extensivos a su familia, aliados y a los miembros de sus comunida. des primordiales continúan en vigor, con las consecuencias que ello tiene para la estructuración y reproducción clasista. El derecho a transferir la propiedad, los ingresos y la influencia siempre ha animado a los recién llegados (y a los futuros recién llegados) a las filas del privilegio a respetar de antemano las reglas que protegen la asimetría en la distribución social de tales bienes. Bajo condiciones de modernidad, sin embargo (que incluyen impuestos progresivos, poifticas sociales de bienestar e ideologías oficiales igualitarias), han surgido problemas en la consolidación de esta inmemorial inclinación. No obstante, la resistencia de la tendencia hacia la desigualdad bajo tales condiciones hostiles es muy notable si tenemos en cuenta cómo la ciudadanía, el medio cultural y político que, según cierta ideología, estaba destinado precisamente a eliminar la desigualdad, es la que en última instancia la ha mantenido y teforzado, aunque sea con nuevos e inespetados criterios.

10. Esto no es arguiir, como hacen Lipset y Zetterberg, que el industrialismo ha entrañado tasas altas y unifornes de movilidad ocupacional en países con economías industriales ( $\mathrm{S}$. M. Lipset y H. Zetterberg, 1959). Hay literatura posterior que indica diferencias notables entre países. El debate es $\tan$ vasto y conocido que me abstengo de dar fuentes en este lugat. 
d) La legitimación de la innovación. La innovación ha evolucionado desde un estadio en la que era temida a otro en que la cultura la ha puesto (en gtan parte) en el altar de la conducta socialmente más valiosa. El ámbito en que ocurre esto último varía de un país a otro. Así, en países de «socialismo» de Estado la innovación ideológica está desterrada, a menos que no sea producida por los ótganos oficiales, mientras que en Occidente las sectas, las iglesias y los partidos la evitan con frecuencia en sus respectivas esferas.

Las consecuencias y ramificaciones de la innovación para la desigualdad social son vatiadas. Mentaré aquí una sola: la recompensa por la innovación (o su sucedáneo frecuente, la novedad mera) suministra un premio sistemático a cualquiera que la produzca. La competencia pata la producción de innovación se hace así muy común. Es muy intensa en aquellos sectores de las clases medias y de las instituciones por ellas colonizadas: centros de pesquisas científicas, universidades, empresas de negocios, agencias de planificación e información. La demanda generada por estos entes crea «innovación institucionalizada» (como ya señaló Schumpeter refutiéndose a las empresas capitalistas) de tal modo que entra en la economía con el orden necesario para que se evite la inestabilidad social. (Schumpeter relacionó convincentemente la violencia tradicional del primer capitalismo con un proceso discontinuo de innovación y con la falta de experiencia de los empresarios respecto a ella.) ${ }^{11} \mathrm{La}$ sed por lo innovador y lo nuevo queda reforzada mediante demandas externas, como lo es la presión de la catrera armamentista internacional sobre las fábricas de armas y tecnología militar o militarizable. Esto a su vez aumenta el reclutamiento ce personal experto según criterios universalistas y mina la formación de una casta autorreproductora dominante. Ello es cierto de Europa y Norteamética aunque to es menos de los países en los que un partido único monopoliza poder e ideología: en estos últimos los imperativos del reclutamiento se hacen notar igualmente, pero éste es filtrado y canalizado por Ia casta partidista dominante. En Occidente, las diferentes vías de acceso y especializaciones ocupacionales para la innovación tefuerzan las pirámides de status relativamente autónomas que existen para la mayoría de carapos de actividad. Algunos de ellos son asaz fluidos internamente. En virtud de tal fluidez la correlación entre logro objetivo y recompensa social - tan a menudo lejos de ser perfecto- ha mejorado en muchos casos, en especial en áreas como la tectnología, en la que es más fácil medir dicho logro en términos de aportación a la innovación.

11. J. A. Schumpeter (1939). 


\subsection{La pluralidad de las jerarquias saciales}

No vivimos bajo una vasta y general jerarquía social, sino más bien bajo una red compleja de estructuras piramidales que se interpretan. (Hago uso aquí de la metáfora de la pirámide a falta de otra mejor.)

El Estado, la mayor de todas ellas, se atribuye soberanía y control en última instancia, peto sus fronteras e influencia no quedan limitadas a su propio territorio, como indican los hechos de la interdependencia y dependencia internacionales. Otras estructuras, como las compañías y asociaciones transnacionales, complican la situación. Estas entidades se interpenetran e interpenetran a otras, locales, de mucho menor alcance. Están Gotadas, además, de grados diferentes de rigidez y cubren esferas distintas de actividad. Los intersticios entre ellas, las zonas de ambigüedad y, para usar la expresión de Simmel, la intersección de los diversos círculos sociales que crean sus superposiciones, pueden ser fuentes de creatividad y libettad. Cuando no crea distancias sociales excesivas y lealtades conflictivas desgarradoras, esta red llena de tensiones, cuyas instituciones se ballan en relación de interdependencia al tiempo que son autónomas entre sí, puede generar una inquietud saludable y creadora para sus miembros en su búsqueda del teconocimiento social y el logro objetivo. Pero las contradicciones y presiones de un universo de tal indole exige también víctimas: de la ansiedad grave a la deriva social, de la anomia a la delincuencia, la situación genera también sufrimiento, privación y desesperanza.

No es fácil, bajo tales circunstancias, montar un movimiento lúcido y racional "contra el sistema», guiado por quienes están marginados por él, dado su tamaño, complejidad y vasto apoyo popular, consciente e inconsciente. Hasta ahora, las recompensas de la redistribución capitalista en combinación con la política social del «estado benefactor» han conseguido encajar los embates del descontento popular generado por la clase y la desigualdad. Ello no ha ocurrido, claro está, cuando tal descontento iba acompañado de otros males, como el paro masivo y la inflación incontrolable. Pero los casos de asimilación son notables. Así la política del New Deal en los Estados Unidos, a pesar de su corta vida, es un ejemplo de éxito sistémico, mientras que el ascenso del nazismo en el marco de Weimar muestra que hay límites a la medida en que los regímenes democráticos pueden absorber la desconfianza y el descontento populares. Sus restricciones son esencialmente políticas porque la represión policíaca no puede ejercitarse en las democracias ilimitadamente, sin peligro de que ellas mismas fenezcan y sean sustituidas por dictaduras: mucho depende por lo tanto de los recursos económicos disponibles para la redistribución por vía gubernamental. Aunque la política de redistri- 
bución y reformismo en la Europa contemporánea ha sido muy considerable (sobre todo si se compara con tiempos pretétitos) ha empezado a encontrar su techo de expansión en su coste económico creciente. Es obvio que bajo el presente orden de desigualdad el coste total para la reducción sustancial del paro y la creación de un sistema justo de educación universal -por mencionar tan sólo dos cuestiones importantes y muy caras- sólo pueden lograrse en condiciones de crecimiento económico sostenido e intenso. Tales condiciones dejaron de existir en 1973.

En gran medida, la presente pluralidad de estructuras interpenetradas de desigualdad ha aligerado el peso que antaño ejercía Ia presencia de una única jetarquía social. Tal plutalidad ha surgido de la autonomización, en el marco jurídico de la sociedad civil, de instituciones y asociaciones de toda índole, así como mediante la apertura de todas ellas a amplios ctiterios de reclutamiento ocupacional supuestamente basados en el mérito individual. Junto a la legitimación de la innovación, ello ha contribuido a crear un ambiente no del todo desfavorabie a las normas universalistas ${ }^{12}$ que permite a las gentes entrar en liza competitiva aparentemente abierta. $\mathrm{X}$ así lo hacen, imbuidas del mito o espíritu vocacional, pues la ideología contemporánea de la personalidad lo exige. Esta aún continúa anclada en la noción de vocación, o Beruf, secular, aunque se resienta de modificaciones importantes y de su desgaste a manos de la psicotecnia y de las normas rutinarias de promoción. Y, según la utopía de la modernidad, la entrada en la arena competitiva debe hacerse como si todos fuéramos ciudadanos iguales, dotados no obstante de capacidades desiguales, certiffcadas cada vez más por diplomas públicos, es decir como Menschen mit Eigenschaften, hombres con cualidades especificas. Tales gentes no pueden ser entendidas como el héroe de Musil, onbe Eigenscbaften, aunque paradójicamente tampoco difieran mucho de él, pues a él no le faltaban las cualidades que del hombre moderno se requieren. Al contrario, al tenerlas todas su creador pudo describirlo como hombre sin ninguna en particular.

EI hecho es que el flujo innovador o pseudoinnovador que ahora se exige de nuestros conciudadanos con ambición de ascensión social ayuda a mantener la capilaridad social, es decir la estabilidad de la desigualdad,

12. La insistencia de Parsons y sus seguidores en el «universalismo» como rasgo de la cultura de las sociedades avanzadas ha sido criticada con razón a ia luz de la presencia del nepotismo, favoritismo y otros criterios particularistas para la cooptación, la promocion y la atribución de bienes. Mas es innegable que en condiciones de modernidad es menester poner en vigor ciertos criterios impersonales y universalistas. Es de esperar que el presente ensayo dé al componente universalista el peso que merece, sin desquiciatlo. 
pues la promoción por aportación a la innovación (y otros méritos, como los gerenciales) se permite a cambio de fuertes concesiones al conformismo en todos los demás terrenos. Adernás, y en contraste con aquellos valores del pasado que excluían del reconocimiento social a un buen número de actividades por considerarse «bajas» o «humillantes», hoy tada persona «destacada» en cualquier campo puede exigir respeto, deferencia y recompensas materiales. Para ello sólo es menester convencer a co lectividades relevantes de la realización de una aportación en un ámbito de actividad, que puede ser de cualquier indole: el deporte profesional, la ciencia, el socorro de los desamparados, la guerra, el teatro, la ingeniería, la religión. En un númeto elevado de casos lo crucial no es ringún valor intrínseco de tal aportación, sino su presentación pública en forma de imagen. Sólo basta su éxito.

La ascensión permanente de los así promocionados depende de critetios especiales de logro en cada canal social de movilidad. (Los promocionados ya no pueden ser entendidos como advenedizos, concepto butgués periclitado.) En cada canal existen jerarquías especializadas en cooptar, conceder y acomodar a los tecién llegados entre las flas de quienes ya ocupan las cúspides, o los puestos intermedios codiciables. De no existir ellas, así como los xitos de paso y títulos necesarios, el hado de las clases gobernantes tradicionales sería perecer. ${ }^{13}$ Pero hoy sus élites han aprendido las artes de la supervivencia. Tienen mucha más práctica que antaño, cuando el nuevo mundo de la modernidad era arduo de comprender visto desde artiba. En virtud de su presente y experimentada conducta las élites de hoy, acomodaticias y abiertas, pueden mantener su clase y ejercer no poco poder: la institucionalización de la promoción social ha resuelto su problema.

\subsection{La antinomia de la ciudadania}

Resumiendo el argumento hasta aquí expuesto: el proceso de modernización ha traído consigo una reducción incipiente y relativa del nivel de Ia desigualdad ${ }^{t 4}$ así como el desarrollo de tendencias igualitarias sustan-

13. Esto es eco de las observaciones de Pareto sobre la conducta de las élites cuando se ven amenazadas por grupos ascendentes, pero no tiene aquí la intención ahistórica con la que él presenta el fenómeno.

14. No excluyo el aumento de la desigualdad en fases primerizas, con su pauperización, trabajo infantil y otras formas de superexplotación. Empero, sea cual sea Ia conclusión del debate sobre la inmiseración durante la Revolucion Industrial entre la clase obrera, los efectos de finales de ésta sobre el bienestar físico de esa clase, a 
ciales en esferas estratégicas de la vida social. ( «Estratégicas» significa que son importantes para el orden social general y no para aspectos aislados - marginales del mismo.) El industrialismo ha creado un excedente económico de proporciones tales que ha podido dar lugar a un cierto grado de distribución sin precedentes en la historia civilizada de la desigualdad humana. Ello ha conducido a un estado de relativa abundancia y bienestar entre las diversas clases subordinadas. Por lo mismo, sin embargo, sus sentimientos de privación relativa e injusticia social han sido exacerbados: 1a reivindicación de derechos redistributivos de tiqueza se ha hecho endémica pero ha tomado una forma contradictoria. Esta dimana de la antinomia esencial de la dinámica de la institución de la ciudadanía, a saber, su inherente igualitarismo nos acerca a sus objetivos sin permitirnos alcanzarlos. Tales paradóficas circunstancias empujan a muchos a exigir mayot igualdad en lo general sin que por ello dejen de hacer innúmeras distinciones antiigualitarias en lo particular. 's Es ese el caso paradigmático de quienes piden mayor nivelación social pero al mismo tiempo exigen el mantenimiento de los diferenciales salariales que fomentan la desigualdad y la discriminación.

La ciudadanía es un proceso constante. Como tal se va redefiniendo y adquiere sentidos distintos en el contexto histórico de la desigualdad. En plena era burguesa era algo que permitía el goce de ciertas libertades y protegía a muchos contra ciertas arbitrariedades y desafuetos aunque nunca lo hiciera contra las lesiones de la clase social. Iba unida también Ia ciudadanía a la vieja corriente histórica europea de la civilidad y las buenas maneras. ${ }^{16}$ No en vano modales y civismo incorporan ambos toda suerte de convenciones que encarnan la práctica de la deferencia y la legitimación de un orden de rangos. Tal práctica ha coadyuvado a hacer más soportables las aristas ásperas de la desigualdad en un mundo capitalista desencantado, es decir, carente de los honores mágicos y la piedad que soportaban la extrema desigualdad en otros tiempos. La debilitación de estas formas de civilidad y hasta las de mero civismo explica que ya no sea posible castigar lát «insolencià de aquellos radicales que desprecian las convenciones sociales heredadas de la era burguesa que hoy agonizan. No obstante, la permanencia de una cultura deferente entre las

partir de $1870 \mathrm{y}$, sobre todo, tras 1945, son indudables. D. Fohlen (1971), pp. 227-228. Algunos marxistas han intentado dar una respuesta adecuada a este fenómeno, sin conseguitlo convincentemente. Así, $G$. Therborn cuando afirma que el capitalismo ha aumentado la explotación relafiva de los trabajadores al tiempo que mejoraba su nivel de vida (sic).

15. V. Pareto (1963), 1220-1227.

16. N. Elias (1978). 
clases trabajadoras - bajo el batniz del discurso igualitario de sus pariidos- asegura que los tadicales continúen en su posición marginal y aislada a pesar de sus explosiones públicas y endémicas de ira, frecuentemente juvenil. ${ }^{17}$ Por otra parte la reivindicación violenta de la igualdad por grupos terrotistas dificulta más aún su reivindicación efectiva por las clases subordinadas por medios pacíficos. El terrorismo por lo tanto exacerba la desigualdad y justifica la represión. ${ }^{18}$

Todo esto ocurre en el marco de una economía capitalista que ha desbordado por completo las fronteras de su antigua cuna geográfica. $\mathrm{Ha}$ surgido un mercado transnacional que liga sociedades distantes en una urdimbre más compleja que nunca de subordinaciones y dependencias. Ėstas ya no pueden considetarse estables. Sólo el auge de los medios técnicos de comunicación ha permitido que algunos rasgos mundiales del metcado y de la estructura de la desigualdad sean percibidos por el gran público. Las ideologías nacionalistas y las distorsiones de tales medios oscurecen una percepción más clara. Empeto, puede notarse el desarrollo de un cierto grado de oposición al orden social imperante menos provinciana, de conciencia menos localista. Hasta ahora se ha manifestado en ámbitos de sobrevivencia bélica (movimiento antinuclear) y ecológica (protección de la naturaleza) y en aquellos más directamente relacionados con la desigualdad (feminismo, antirracismo, lucha contra la pobreza). Pero las características de este universo continúan mudando bajo las oleadas sucesivas de la innovación técnica y las embestidas que se dan unos a otros mundos sociales diversos: Isłam, Occidente, los países tecrobutoctáticos «socialistas», y vatios otros complejos mactoestructurales, que a veces se entrecruzan entre sí. Ello conducirá a mayores transformaciones aún en la estructura mundial de la desigualdad y eventualmente a la desaparición de la problemática que la domina en su forma hoy presente.

\section{ESTADIOS EN LA HISTORIA DE LA DESIGUALDAD SOCIAL}

Estos asuntos hasta aquí tan someramente esbozados, merecen un examen más pormenorizado. Para conseguirlo empezaré por volver atrás y adentrarme en la dimensión histórica de la desigualdad para pasar en

17. De Berkeley, California, 1964, a Zurich, 1980, y Viena, 1981. La revuelta estudiantil francesa de 1968 puede considerarse uno de los momentos cumbres de esta situación, aunque quizá más interesante sociológicamente sean los provos halandeses y otros movimientos neolibertarios de años subsiguientes.

18. S. Ginet (1982), b. 
seguida a seguir sus huellas en su actual dinámica, desvelando su compiejidad en la medida en que me lo permitan los límites de un análisis como el presente.

\subsection{El cierre social $y$ sits fases}

Cierto es que la desigualdad es consecuencia del orden económico, político y cultural de la sociedad. Pero la desigualdad es mantenida y conformada también por el cierre social. El cierre es el proceso por el cual ciertas posiciones sociales son teservadas activamente por ciertas gentes para sí mismas o para otras específicas, con exclusión de las demás. A nivel mictosociológico el cierre entraña la atribución de una posición a un individuo dado por razones de discriminación, y no a otros. A nivel macrosociológico significa la distribución discriminatoria de ingresos, au. toridad, poder, propiedad, empleo y privilegio a categorías específicas de individuos con exclusión de otras. ${ }^{19}$

Los estudiosos de la sociedad se han interesado, sobre todo, por aquella forma de cierre que dimana del sistema clasista y han dedicado también mucha atención a la transición de la desigualdad feudal preclasista a la clasista, bajo el capitalismo. Menos atención ha recibido la transición del clasismo capitalista a un nuevo orden de desigualdad, si bien la literatura existente sobre la aparición de una sociedad «postmoderna» trata de ello en cierto modo. Lo cierto es que numerosos estudios sobre las clases en la sociedad contemporánea, hasta cuando toman en consideración las mu. danzas de su composición interna, ignoran las señales de que surge un sistema realmente nuevo de desigualdad. Aquí intentaré considerar tal posibilidad. Para eilo comenzaré por suponer la transición de una sociedad es. tamental a una sociedad corporativa a través de un estadio intermedio, la sociedad clasista. La sociedad clasista clásica será considerada, por lo tanto, como una fase entre otras y, como tal, no particularmente duradera. Será observada corno puente entre otras dos formas históricas de

19. La noción de cierre de clase es importante ya en Marx, aunque solo por irnplicación. También lo es en Pareto, aunque su énfasis es sobre los procesos de exclusión que la acompañan. V. Pąreto (1963) 2025-2029. Weber empezó a usarla de modo más sistemático, aunque su preocupación por la «situación de clase» le condujera quizás a no explorat demasiado la cuestión del cierre como tal en cada clase. Sin usar la expresión, Schumpeter estudió el fenómeno a través de sưs conceptos de la «pattimonialización» de los atributos clasistas y el proceso de «atrincheramiento de clase» (J. Schumpeter, 1962, pp. 163.221). Ha recibido atención más explicita por parte de estudiosos de la reproducción clasista como Bourdieu y Passeron, y Touraine. C. A. Touraine (1977), pp. 276-290. Explícitamente reavivado por F. Parkin (1980). 
desigualdad, una de ellas en el pasado distante y la otra empezando a perfilarse bajo nuestra vista.

En la historia de la estructura social europea, y aparte de las importantes variedades que aparecen dentro de ella en cualquiet momento, apatecen tres grandes modos sucesivos de organización general de la desigualdad social en los tiempos modernos. Pueden recibir los nombres convenientes de sociedades estamentaria, clasista y corporativa. Pueden caracterizarse, en escorzo, así:

a) La sociedad estamentaria corresponde aproximadamente al período tatdío del feudalismo. En este orden social las gentes estaban divididas en estamentos y no en clases, aunque la presión para su transformación en clase era ya notable. Esa división estaba reconocida legalmente y sancionada por fuerza, ideología y costumbre. La presencia abrumadora de la economía tural feudal en el masivo sector agrícola permitía la fragmentación de la sociedad en una miríada de estructuras verticales de subordinación (con frecuencia encamadas en vasallaje) que imposibilitaban alianzas antagonistas horizontales entre los estratos subordinados contra los dominantes. El ascenso del primetizo Estado moderno con su concentración de poder en un «señor central» (para usar la expresión de Elías) o soberano permitía la coordinación efectiva del estamento dirigente, la nobleza, en su función de dominio. No obstante, la fragmentación feudal y la relativa debilidad del poder real durante muchos siglos habían permitido ya el crecimiento de burguesías mercantiles poderosas y de un industrialismo "preindustrial» en las ciudades. Un conjunto de inventos - desde la contabilidad a doble entrada a la imprenta- y una cultura que permitió su adopción general pronto unió al estamento burgués a formas más seculares y racionales de legitimación de la politeya. Éstas prevalecieton a la postre: cesó el vasallaje como ligamen político y económico principal de la sociedad.

b) La sociedad clasista corresponde al período de la hegemonía del individualismo posesivo burgués. Incluye una fase inicial en la que se hizo predominante el compromiso y acomodación mutuas entre el estamento dominante de la última era feudal y la nueva burguesía, salvo durante breves períodos revolucionarios en algunos países; una fase de plenitud en la que el dominio burgués se ejercitó sin trabas; y una fase final de declive burgués relativo durante ei cual la burguesía tradicional debe hacer concesiones a las organizaciones de las clases subordinadas (sindicatos) al tiempo que la institución principal de capitalismo es la gran empresa. En esta fase muchas empresas se integran en monopolios, oligopo- 
lios, trusts y cartels. A través de estas fases diversas la sociedad de clases, aunque dependía en gran medida para su equilibrio interno de los mercados ultramarinos, se desarrolló dentro del marco del Estado «nacional». Era un orden político garantizado por el Estado (como entidad separada del resto de la sociedad, o sociedad civil), el cual cooperaba en mantener las pautas de cierte de la época en ausencia de las batreras que antes mantenía la religión y el temor a las cualidades míticas de clero y nobleza, con su sanción divina. La secularización avanzada, combinada con una no existencia legal ni ofcial de la clase social, creó un vacío en torno a la legitimidad de la desigualdad. Sólo la educación diferencial y el mantenimien. to político de los sacrosantos derechos de la propiedad (ambos ayudados por el Estado) hizo de la clase el criterio principal de la desigualdad.

c) La sociedad corporativa corresponde al período del capitalismo mun. dial maduro y de la incipiente crisis del Estado «nacional» totalmente soberano. (Ni tal crisis, ni la crisis paralela de la sociedad civil ${ }^{20}$ se extiende todavía al aparato de Estado mismo, paradoja que sólo puede explicarse mediante una discusión más detallada de la nueva situación.) La clase social continúa existiendo como componente crucial del sistema de desigualdad. No obstante, la clase queda determinada ahora sobre todo por la estructura ocupacional, así como por la integración de las personas en la nueva unidad de estructuración social, la corporación. Esta unidad social sobresale en una sociedad en la que tantos son empleados asalariados y miembros de instituciones formales. La corporación dicta en gran manera las oportunidades (Lebenscbacen) de sus miembros y los criterios para la inclusión, la exclusión y la promoción social, aunque no todos: la segregación racial o el prejuicio sexual, por ejemplo, tienen orígenes diferentes. Pero las corporaciones pueden incorporat tales criterios. El cierre social queda ahora mediatizado por la corporación. Ésta puede definirse como una asociación organizada jerárquicamente, administrativamente integrada, y orientada hacia haces específcos de fines bajo una ideología de maximación de resultados.

En las sociedades avanzadas, hay un número creciente de corporaciones que pertenecen al Estado (él mismo es una corporación más) o a sus ramas y sucursales, mientras que muchas otras son privadas o semiprivadas. Las condiciones contempotáneas de monopolio y oligopolio, em. pero, han dado una nueva significación a la noción de lo privado en lo que atañe a tales instituciones. Las corporaciones, por lo tanto, son de índole muy diversa, e incluyen ministerios, universidades, bancos, organis-

20. S. Gincr (1981). 
mos internacionales, compañías nacionales y multinacionales, grandes partidos políticos, fábricas, municipios, hospitales, sindicatos, ejércitos, empresas de informática y comunicación. En su conjunto no agotan todo el ámbito de la sociedad humana ni regulan su vida por completo. (Aunque tal sea el objetivo de la ideología tácita del corporatismo, de la utopía cotporatista. $)^{21}$

El desarrollo interdependiente de las corporaciones en el mundo moderno ha sido el resultado de la confluencia de varias cortientes importantes, entre las que descuellan la lógica de la concentración y acumulación capitalistas, el auge de los nuevos modos técnicos de almacenar y manipular la información y el conocimiento, y el uso sistemático de la innovación técnica para la maximación de los resultados, sean éstos cuales sean, desde la destrucción bélica a la eliminación de la enfermedad, pasando por la producción de alimentos, el entretenimiento masivo y la difusión de las noticias. No hay que olvidar, entre estas corrientes, una esencial, y que dimana de su presencia conjunta: la necesidad de coordinar un universo social cada vez más denso, y una de cuyas facetas es precisamente la densidad corporativa. Bajo condiciones de secularismo relativo y burocratización avanzada el Estado ha venido a set la única corporación capaz de la cootdinación imperativa de este vasto y complejo conjunto institucional, sobre todo siempre que el orden «espontáneo» de la sociedad civil cede ante sus propios conflictos y debilidades.

A pesar de todo ello el legado del sistema legal autónomo liberal, na* cido y en gran manera desarrollado en los períodos precedentes, continúa siendo un componente esencial de las sociedades corporativas occidentales y relativamente pluralistas. Tal sistema, sin embargo, se vuelve recesivo ante el peso de ia política de intereses sectoriales o grupales, y la de las corporaciones mismas. Además, como quiera que sus taíces sean agnósticas en lo religioso e individualistas en lo humano, la ley encuentra diff-

21. EI crecimiento del aparato estatal y el de su peso sobre el testo de la sociedad apenas puede exagerarse. En el país más aferrado a su sociedad civil, los EE. UU,, en 1979 más de la mitał de la población tecibía o derivaba ingresos de fuentes gubernamentales (un 51,2 por 100). El porcentaje de individuos empleados en el gobierno federal, estatal o local (con sus dependientes incluidos) era de un 12,8 por 100, New York Times, 1 de febrero de 1981. La señora Thatcher, pos su parte, fue elegida en 1979 con promesas de disminuir y hasta desmantelar el aparato estatal. No obstante, la proporción de empleo público como porcentaje del empleo total continuó aumentando (de un $29 \%$ a un $30 \%$ a principios de 1983). Con una disminución de sólo un $4 \%$ en cifras absolutas (que incluyen las industrias nacionalizadas), el peso del sector público aumentó en Inglaterra a pesat de la recesión y de la ideología militante del gobietno. Londres: Central Statistical Office: Economic Trends, matzo 1983. Tambien The Times, 15 marzo 1983, editorial, p. 13. 
cultades crecientes en legitimar el sistema de desigualdad del sistema corporativo. Éste, en cambio, es muy congruente con la creencia en la autoridad técnicamente experta. El problema es que, como Weber indicó, la legitimación moral y politica no puede, en últirna instancia, dimanar ni de la ciencia ni de la técnica. Y las sociedades avanzadas muy a menudo se apoyan en la autoridad técnicamente experta para legitimar el mantenimiento y desarrolio de la desigualdad. ${ }^{2}$

\subsection{La sociedad corporativa.}

Como el último de estos estadios en la historia moderna de la desigualdad es el más nuevo y el que más sujeto se halla a controversia, son menester algunas puntualizaciones. Se refieren a tres cuestiones distintas: mi definición y elección de la corporación como unidad de observación; el lugar de mi conceptualización en el debate actual sobre corporatismo; y la elección del término «sociedad corporativa» para caracterizar el orden social emergente.

1. Las corporaciones, se afirma, son asociaciones administrativamente estructuradas. Si tal definición se mantiene no hay nada confuso en que cubra por igual entes sociales tan diversos como ciertas empresas comerciales, sindicatos grandes, ministerios estatales, partidos políticos madutos. Tal definición no ignora los fines diversos de cada una de ellas. Al contrario, en contraste con comunidades, clases y otros colectivos, las cotporaciones se definen aquí por su especificidad funcional, así como por su tratamiento jerárquico y formalizado de conjuntos de problemas en sus esferas de competencia en la vida social. Por ello, las distinciones elementales entre corporaciones económicas, políticas, educativas, sanitarias y demás sólo pueden fortalecer la definición. Así ocurre también con otras distinciones, como la que cabe hacer entre corporaciones públicas, monopolistas privadas y pluralistas privadas. Además la definición deja sitio para la necesaria conciencia histórica del hecho de que las iglesias, los viejos gremios, el Estado premoderno y otras entidades son corporaciones tradi. cionales que prefiguran las contemporáneas. Por último, es compatible también con una posible taxonomía de corporaciones contemporáneas y con su graduación en orden de importancia para la continuidad y la prosperidad social. En tanto en cuanto la definición coincide con lo que suele llamarse «organización formal», puede integrarse en su campo de estudio. El aná-

22. J. Habermas (1968). 
lisis de la sociedad moderna como sociedad corporativa nada tiene que discutir a aquellas interpretaciones que afirman que vivimos en un mundo de organizaciones siempre que éstas no sean concebidas como monopolizadoras de toda la vida social ni se suponga que se entrelazan armoniosamente en un conjunto libre de conflicto.

2. Existe un intenso debate sobre el desarrollo del "corporatismo» en nuestros días. Las posiciones sobre la naturaleza del fenómeno difieren, peto la mayoría lo ven confinado a un proceso triangular entre gobierno, sindicatos y empresarios. Algunos ven en él una entente semicordiale entre los tres protagonistas, orientada a la buena gerencia de la economia capitalista en su presente fase avanzada. Para ellos la intervención e intermediación estatal entre trabajo y capital, así como la inversión estatal en la economía capitalista son cuestiones decisivas. ${ }^{23}$ Sin olvidarlas en absoluto, la visión que presento trasciende esta interpretación de las rela ciones tripartitas entre el gobierno, la gerencia de la empresa pública y privada y los sindicatos; deben tenerse en cuenta, pero, a pesar de mayores dificultades de teorización, es preciso tomar una perspectiva más amplia. Es más interesante entender el corporatismo como la presencia hegemónica en la sociedad moderna de varias especies distintas de corporación y no sólo de las estrictamente económicas. Son las corporaciones de todo género, en su modo común de estructurar la interacción social y coordinar la conducta de una pluralidad de individuos, las que se han convertido en pivotes del orden social contemporáneo. Ello ha ocurrido como resultado de una coalición de eventos y corrientes históricas ya mencionados. Conviene recordar que ellos no quedan confinados a la esfera de la empresa. Ésta, claro está, en su faceta administrativa y burocrática, ha encontrado eco en muchas otras zonas de la vida social. Su modo de calcular el riesgo y reducirio, su buena administración interna, sus estrategias de expansión, su visión secular, realista y mundana de las cosas invitaba a su triunfo como paradigma de organización social eficaz. Pero ha habido otras fuentes históricas de corporatización: la Iglesia, por su Iado, con siglos de experiencia en el desarrollo de una burocracia internacional canónica, y el Estado, por otro, en su proceso de lenta e incompleta domesticación de la violencia privada y su unificación militar y polićaca, amén de su mono-

23. Para esta visión restringida, que frecuentemente sostienen escritores matxistas, cf. B. Jessop (1979) y L. Panitch (1980). Para la distinción entre el corporatisno contemporáneo y el «corporativismo» fascista, P. Schmitter (1977). Ya A. Shonfield en 1956 (pp. 230-233) se quejaba de las confusiones entre el fascismo y el corporatismo democrático (sic). 
polio de la contribución fiscal al erario y creación de un solo tesoro público.

Tampoco es posible concebir la naciente sociedad corporativa como una mera "empresarización» del mundo doblada de butocratización continuada. La cosa no estriba en una sencilla continuación weberiana de la burocratización. La corporatización nos lleva más allá de la burocratización, a un plano cualitativamente diferente: el de las relaciones intetcorporativas y el de las telaciones entre las corporaciones y las otras facetas de la vida social, como son la clase social y las formas nuevas de poder y privilegio.

3. Mi uso de la expresión «sociedad corporativa» no debería ser polémico. No tiene pretensión ontológica alguna sobre la naturaleza de la modernidad madura. Sólo intenta poner de relieve algunos de sus tasgos sobresalientes. En el terreno de la desigualdad y la estructura social, parece más elocuente que otras expresiones. Así, la expresión de «sociedad postmoderna» parece vaga y nos obliga a establecer las fronteras de la modernidad. La de sociedad «postcapitalista» está ideológicamente tergiversada, pues se suele aplicar a sociedades que son muy capitalistas. La «tecnostructura» se refiete a un aspecto, el económico, de lo que aquí se indica por sociedad corporativa. El poco feliz término «sociedad masa» sólo se refiere a algunos aspectos del orden social a que nos referimos. En todo caso la exptesión que empleo se usa por mera conveniencia, a falta de otra mejor, y no pretende sustituir a las demás enteramente.

\subsection{La evolución de la desigualdad}

Hechas estas aclaraciones, volvamos ahora sobre los aspectos históricos de la evolución de la desigualdad con especial referencia a la cuestión del cierre social.

La tendencia histórica de largo alcance en la producción de bienes y excedente económico no parece demasiado problemática, a pesar de sus fluctuaciones. Suele presentarse como curva exponencial, ${ }^{24}$ en la que se ignoran desviaciones periódicas menores. Algunas de estas últimas fueron importantes. Puede asumirse, así, que los efectos de la pax romana, con su explotación sistemática de la minetía, los cereales, la navegación y el transporte terrestre debe haber aumentado la producción en la era clásica tardia. Esto contrasta con la situación siguiente, en los siglos oscuros, con

24. W. W. Rostow (1978), pp. 1-100. 
el declive en el comercio y la artesanía. A pesar de serios reveses en al. gunas partes, como en la otrora próspera cuenca mediterránea, el Renacimiento presenció los orígenes de un aumento en bienes agrícolas que, combinada con la acumulación de riqueza generada por los imperios ultranatinos europeos, entrañó el nuevo despegue de la curva, la cual estaŕáa destinada a recibir Ia conocida aceleración producida por la Revolución Industrial a partir de 1750 . Mas no sería prudente proyectar esta curva en el futuro siguiendo el trazo de su reciente trayectoria: por poco fiables que sean las conclusiones extremas de algunos pronósticos pesimistas so bre el agotamiento rápido de los recursos económicos, es muy posible que los límites sociales (y no solamente energéticos) del desarrollo ${ }^{25}$ fuercen cambios sobre esa tendencia. La predicción del declive absoluto puede estar tan mal fundamentada como la del crecimiento exponencial continuado, a menos que estalle una tercera guetra mundial. Más juiciosa es la predicción de un declinar futuro de la tasa de crecimiento. Ello nos daría una curva histórica general, desde la Edad Media, en forma de S. Esta podría ser también la curva del tamaño de población en la zona del mundo que se examina.

Teniendo en cuenta que existe, como se mostró antes, una relación definitiva entre el tamaño del excedente económico y el grado general de desigualdad social, sería interesante analizar este último históricamente, comparando sus fluctuaciones con las de la población y producción de bienes. Comoquiera que las corporaciones son entidades esenciaimente jerárquicas, de desigualdad estructurada, ello podría hacerse quizá contemplando la evolución del corporatismo, es decir, su extensión e intensidad a través del tiempo. Inevitablemente, ello debe ser muy especulativo. Además, si el corporatismo se define como fenómeno estrictamente moderno, sus orígenes también deben serlo. Así, si relacionamos las corporaciones con las organizaciones de servicio público estrictamente burocráticos nos veríamos obligados a hallar sus orígenes sólo en el siglo xvIII. Antes de él ningún Estado, ni siquiera Prusia, poseía nada que cumpliera los requisitos de una burocracia moderna de servicio público, si bien al gunos países se acercaron a ese modelo. Ese fue el caso de la administración imperial española, consolidada en el siglo xvi. ${ }^{26}$ No obstante, no sería sociológico ignorar el elemento cotporatista de la administración romana, presente en su heredera, la Iglesia católica, así como el corporatismo municipal medieval, los registros y oficinas continuos de ciertos rei-

25. F. Hirsch (1977).

26. G. E. Aylmer (1979), pp. 167-168. 
nos (sobre todo Inglaterra) y el desarrollo de gremios, ordres y Stände con características protocorporativas.

Podría asumirse que en las civilizaciones preindustriales la curva hipotética resultante de la presencia agregada de protocorporaciones es grosso modo paralela a las curvas de población y producción de bienes. La corsplejidad asociativa va pareja a la densidad social y material. Así, la disolución del orden político romano en la mitad occidental del Imperio presenció el rápido declinar de los collegia y los cargos públicos. Los tiempos tempranos medievales tzajeron consigo la descorporatización forzosa de la sociedad, con su aumento de movilidad, migraciones, invasiones y la inseguridad permanente creada por las bandas armadas. La consolidación de reducidas esferas de poder regular territorial en el marco de un orden feudal tampoco permitió el protocorporatismo, aunque sus más remotos orígenes deben hallarse en las gradaciones y jerarquias internas de la épo. ca. Sólo el corporatismo medieval urbano prefigura el que más tarde había de cristalizar, pero es evidente que su triunfo ya indica un ascenso de la tendencia a la corporatización. Cuando aquél empezó a disolverse, sus semillas, en forma de los primeros bancos medievales y las primeras compañias metcantiles, ya germinaban. Continuarían creciendo quedamente a través de la primera gran era de la clase social, la del capitalismo temprano, como así lo hacían las ramificaciones del Estado. No obstante, su peso conjunto en la función de articular y dar coherencia a la sociedad entera exa de segundo orden si se compata con el gran empuje de la Revolución Industrial y con el poder integrador (aparte de sus fuerzas disgregadoras) del mercado capitalista en expansión. Los dos primeros tercios del siglo xrx fueton así un período de declive aparente para la corporatización, sobre todo en la esfera de las clases subordinadas (con la posible excepción de Alemania). Los gremios habían sido disueltos, los sindicatos estaban prohibidos. El gobierno era inmune a la noción del Estado benefactor y adverso a gerencia de la economía; su presencia se sentía sólo cuando era necesaxio el proteccionismo, cuando eran necesarios los ciudadanos para fines militares, o cuando era menester crear un sistema educativo general, aunque fuera en el seno del privilegio burgués. Sin embargo, andando el tiempo, la militarización, los servicios postales, las escuelas, las carreteras, penetraron las periferias internas de cada Estado y por lo tanto la presencia del gobierno y de la administración pública se hicieron presentes por doquier. Fue así cómo, al final, el Estado transformó las vidas de las vastas poblaciones campesinas de Europa ${ }^{27}$ para quienes el Estado y hasta la nación eran entidades desconocidas. El primer

27. E. Weber (1976). 
aumento agudo de corporatización societaria ocurrió mediante una mejota de las técnicas de imposición y control fiscales, la toma de tesponsabilidades sanitarias y de bienestar por parte del poder público, el auge del partido «de masas», burocráticamente organizado y otros fenómenos semejantes. Todo ello había ido conformándose durante los decenios anteriores a la gran guerra de 1914, aunque sólo unos pocos se dieran cuenta entonces de sus consecuencias últimas para la estructura social, ${ }^{28}$

La influencia exacta de estas corrientes históricas sobre el grado genetal, societario, de cierre es hipotética. Desde el punto de vista de la corporatización es muy posible que el cierre social alcanzara una temprana cima (no muy alta) con la madurez de la administración imperial romana en su época tardía. No obstante, ello fue precedido de un largo período de decadencia en la rigidez clasista, ilustrado por las oleadas de advenedizos que entraton en el servicio público, la extensión de la ciudadanía, la desaparición de la yieja aristoctacia, la prosperidad provincial, la promoción militar y el auge de las nuevas clases medias en mucbas partes del Imperio. En épocas posteriores puede suponerse que el cierre social fue parejo al grado de corporatización. Así, el corporatismo medieval -tanto el gremial como el estamental-- es señal de endurecimiento e índice de rigidez y formalismo.

$\mathrm{La}$ disolución del corporatismo medieval y del feudalismo - ambas cosas, aunque íntimamente telacionadas, no eran lo mismo- trajo el aflojamiento de muchas estructuras. Al margen de las vicisitudes exactas del cierre social en su relación con el corporatismo primitivo, el advenimiento del liberalismo y de la Revolución Industrial significó un cambio muy serio de orientación, que es el que realmente distingue al corporatismo anterior del moderno. La nueva empresa, oficina administrativa, firma o unidad de servicio empezaron a reclutar y promover talento paulatinamente según criterios de eficacia y no de status heredado. Esta reorientación se explica en considerable medida por la lógica de la desigualdad bajo condiciones industriales en el seno de una cultura que valora la maximación de los resultados según el criterio de la eficacia. Un etbos maximizador y su ideología cortespondiente deben evitar las siempre presentes tendencias hacia la osificación, el favoritismo y el nepotismo, o hallar una fórmula de compromiso y equilibrio entre sus propias exigencias y las de estas últimas.

Una conclusión señalada a extraer de esta reorientación sería que mientras que la corporatización -en unión del aumento masivo del excedente económico- ha reducido relativamente el desnivel general de la

28. Entre ellos Burckhardt, Weber y Michels. 
desigualdad, ha aumentado también la jerarquización en el seno de la sociedad de clases. La jerarquización en las redes ocupacionales ha significado la aparición de nuevos criterios de cierre y acceso al poder, privilegio e ingresos, aunque haya entrañado mayor apertura para el reclutamiento inicial en muchos casos. La apertura ha ocurrido externamente, por así decirlo, en la sociedad entera. El cierre ha ocurrido internamente, dentro de las instituciones corporativas.

Así pues, la desigualdad social general o societaria debe separarse cuidadosamente de la desigualdad institucional interna. Si se aplica al pasado, la distinción es puramente analítica. Aplicada al presente es mucho más real. Debemos supotier que la desigualdad societaria - por alta que deba parecet a igualitarios y demócratas - no va hoy necesariamente en aumento, aunque el cierre clasista no sea precisamente desdeñable. En cambio, la desigualdad institucional interna formada por jerarquías ocupatendencia principal. En este contexto puede notarse una importante concionales se sigue extendiendo con el crecimiento de las corporaciones y con la creciente distancia de sus cadenas de mando y autoridad. Esta expansión no es idéntica en todas partes, y pueden notarse algunas contracorrientes, como los esfuerzos en muchos lugares de Europa por crear una democracia industrial, ${ }^{29}$ pero su fuerza no es suficiente para invertir la tradicción en el orden social de la desigualdad, pues ambas tendencias topan entre si de algún modo. Es obvio que debe existir algún grado de congruencia entre los dos génetos de desigualdad, la institucional y la so. cietaria. Tal congruencia mínima se obtiene, y la contradicción se «resuel. ve», en parte, a través de la ideología corporativa del igualitarismo amis. toso, el compañerismo empresarial, que constituye una concesión necesa* ria a los valores democráticos de la cultura predominante. No obstante, esta ideología suele incorporarse solamente en tos modales de la empresa, el sindicato, la universidad, el partido, y hasta en los de los ejércitos, sin altetar la estructura teal de su poder y autoridad. Ciertos consejos consultivos y asamblearios pueden llevar esta ideología un paso más allá, sin poner en entredicho dicha estructura.

La corporatización avanza hoy en día en Occidente a un ritmo mayor que la población y la producción de bienes, La gran densidad de pobla ción, combinada con presiones igualitarias para la tedistribución de bienes (salarios altos, servicios sanitarios, jubilación) y un aumento de la escasez bajo condiciones de tecnología avanzada exige hiperreglamentación y fomenta el desarrollo de instituciones laicas de control social. La congestión crea corporatismo. La corporatización debe alcanzar su techo un buen día,

29. International Research Group (1981). 
pero de momento su tasa de crecimiento no muestra señales de que haya llegado a alcanzar las zoras altas de la curva en S. Esto contrasta con otras tendencias (población, recursos) cuyos ritmos respectivos de crecimiento las han alcanzado ya, aunque sea precipitado hablar de su estancamiento y mucho menos de su incipiente declive. Consecuencia de ello es el corolario de que todo discurso político sobre la desregulación gubernamental y todo plan oficial de desmantelamiento de buroctacias debe considerarse como síndrome de una enfermedad, y como signo de los albores de una sociedad menos hiperotganizada.

\subsection{Transicion en la modernidad}

Uno de los temas principales de la teoría social moderna, si no el tema principal, dicese, es el de la «gran transformación», la vasta transición del mundo tradicional al nuevo. ${ }^{30}$ Mis observaciones tentativas sobre la historia de la desigualdad van unidas a esta preocupación común. No obstante me interesa más aquí la transición que ha ocutrido en la modernidad que el pasaje $a$ la modernidad. La transición en la modernidad ha supuesto una reorganización, en plena era moderna, de la estructura de la comunidad, la clase, la asociación, así como una nueva oleada de formas de conocimiento, derecho y moral apenas perfiladas anteriormente, en los orígenes de esa era. Estos últimos elementos han mudado, una vez más, el lugar del hombre en su universo al redefinir no sólo los límites, sino el sentido mismo de su libertad.

Algunos de los pensadores que hablan del ascenso de una sociedad postliberal, postmoderna o postcapitalista participan de esta intuición de novedad genuina. Otros, mientras afirman los principios de una nueva situación, la ven sólo como continuación, en nueva guisa, de la anterior. El vislumbre de la edad presente en términos de capitalismo «tardío» u «organizativo» es un ejemplo de sutil rechazo de cualquier noción que pueda poner en cuestión la explicación del novísimo mundo en términos distintos a la teoría de la gran transición de la era tradicional a la burguesa. $^{31}$ Para estos analistas la escala de la mudanza ha quedado atada a

30. El clásico de K. Polanyi (1944) dio nombre al fenómeno, pero un número considerable de obras clave (Marx, Comte, Tönnies) han sido elaboradas en tono al tema.

31. Paradójicamente teóricos como Habermas que en su momento afirmaban aceptat las concepciones revolucionarias del mundo de la tradición matxista son quieres siguen una vision tradicional para captar aspectos novísimos de la modernidad. EI enfoque de Habermas y Offe frente a la sociedad corporativa (el «capitalismo organt- 
los dos términos, a qui y ad quem, del gran paso histórico del feudalismo al capitalismo. Quizá su interés creado en el mantenimiento de las posiciones teóricas recibidas no les permita aceptar la presente situación como comienzo de otro novus ordo saeculorum, imprevisto en su utopía y desde luego mucho más prosaico que ella.

El hecho de que el último novus ordo -i de la burguesía- no fuera muy duradero presenta sin duda un problema para la teorización de la sociedad que hoy va tomando cuerpo. Aquel último orden, que ahora toca a su fin, fue esencialmente transitorio, y en un sentido más intenso que el de otros órdenes sociales ello parece claro si reinterpretamos la «era de la clase social» como transición entre dos modos más estables y claramente estructurados de dominación y cohesión sociales. (Estables no significa forzosamente más pacíficos.) Ello entraña relegar la era clasista capitalista a un plano menos prominente que el que ocupa en algunas interpretaciones históticas, aunque no signifique negar su enorme importancia histórica ni mucho menos la de la presencia continuada de las clases bajo las nuevas circunstancias. (Un resultado lógico de esta operación sería la reorientación de la teoría social hacia una visión nueva, más sobria, de las potencialidades de nuestra civilización: la clase o, mejor dicho, la era de su supremacía como unidad principal de la desigualdad ha sido tan decisiva, tanto en lo objetivo como en el reino del pensamiento, que cualquier aceptación de su pérdida de centralidad deberá acarrear consecuencias considerables para el sentido de nuestra visión.)

Sería fructífero, pues, si pudiéramos redefinit los términos de nuestra transición histórica, si el foco de nuestro interés, en vez de caer sobre la transición del feudalisno al capitalismo, cayera sobre el paso del primero a la sociedad corporativa a través de la sociedad ciasista burguesa. En su virtud, la interpretación de otra transición menor -la que va de la sociedad burguesa a la corporativa- también sería entendida de diferente manera. Imaginemos que, en lo que respecta a la desigualdad social, la historia moderna del occidente europeo fuese vista como transición de una sociedad de «órdenes» ligada a una legitimación sobrenatural y tradicional del rango, a una sociedad de «corporaciones» basada en la justificación utilitaria de las asimetrías y subordinaciones mundanas. Ello nos obligaría automáticamente a contemplar la fase burguesa, basada en la clase, el beneficio privado, la inversión privada y la concepción individua*

zacionals) es entenderlo como estadio crítico en el modo de producción capitalista. J. Habermas (1975), pp. 33-34, y C. Offe (1972). El acercamiento de Habermas, en fase posterior, a la teoría de sistemas podría ser un correctivo serio de su posición inicial. 
lista del derecho como intermedia y transitoria. Concluiríamos entonces que si la fase burguesa pudo mantenerse por un tiempo - a despecho de sus desgarres considerables- como orden social viable, ello fue así porque se produjeron unas circunstancias que compensaron y contrapesaron las dislocaciones al capitalismo en expansión. Una de ellas fue la ya mencionada expansión en la producción industrial de bienes y su tebose distributivo sobre la población; la extensión progresiva del voto político, la modernización de las periferias internas; las emigraciones ultramarinas; et ascenso de nuevas clases medias con su consiguiente absorción de sectores sociales excedentes de otras más bajas; y por último, la duradera paz europea. (Los "cien años de paz» de Polanyi, que van del Congreso de Viena en 1815 hasta 1914 con la breve interrupción de la guerra francoprusiana de 1870.) Por todas estas razones ese período de intensa mudanza no fue un «tiempo de disturbios» (como suelen llamar los histo. tiadores ciertas fases desordenadas e inseguras de las civilizaciones), si bien podtía argüirse que los europeos exportaton sus disturbios a través de la expansión imperial, tanto comercialmente como mediante el uso de fuerzas expedicionarias en sus distantes guertas coloniales. Lo cierto es que el periodo se caracterizó por una estructura social livianamente trabada, muy adaptable, e inherentemente cambiante, la cual, por la naturaleza misma de su lógica, no podía durar mucho tiempo. El orden social del capitalismo durante la época en que el empresario y su firma eran ya hegemónicos, ya parejos en el poder al Estado y al gobierno fue, aunque no del todo efímera, sí esencialmente transitoria.

La relativamente rápida reorganización corporativa de la sociedad siguió a tal fase paradigmática burguesa. Sólo muy metafóricamente es esta reorganización un paso hacia la "refeudalización», aunque autores hay ${ }^{32}$ que así lo creen. Quizá haya un adarme de verdad en la noción de que existen similitudes entre los dos órdenes, pues ambos presentan situaciones de monopolio y oligopolio de poder, en ambos las jerarquías verticales controlan y penetran las hotizontales, dominándolas, y en ambos existe, desde cierto punto de vista, una primacía de lo político sobre lo económi co. Mas las diferencias son demasiado pronunciadas para abonar una discusión detallada. Recordemos tan sólo que mientras que las corporaciones modernas suelen acaparar áreas de competencia según criterios de especialización funcional, las feudales fundían sus jutisdicciones en instituciones únicas, ligando además la Gemeinschaft a la Gesellschaft.

Las esferas de competencia en las corporaciones de hoy siguen en

32. Cf. I. L. Horowith (1980), p. 145, sobre semejanzas del mundo postcapitalista con el postfeudal. 
principio criterios analíticos y técnicos de eficacia, de manera que escinden el mundo según planos diversos. Uno, muy general, es el que separa ei reino de lo privado del de lo público. Es ésta una distinción técnicamente esencial que se presta, sin embargo, a violaciones jurídicas constantes. Siempre que una corporación se declara de hecho competente en lo privado - como ocurre con ciertas prácticas de la policía y con el espionaje, ser oficial o "privado», y con los servicios de inteligencia (sic) y vigilancia-, tal corporación transgrede el derecho liberal sobre el que se basa la cultura política y el orden constitucional occidental. Otra distinción, igualmente señalada, es la que separa la esfera de competencia de cada corpotación del resto de la realidad. Las transgresiones son aquí de dos génetos: las de detecho y las de externalidad. Las de derecho implican un asalto violento a un medio ambiente refractario a los intereses de la corporación. Buen ejemplo de ello es el de la compañía multinacional que financia unas elecciones o la subversión armada, según convenga, en países que forman parte de su mercado. Las externalidades de las corporaciones económicas -polución aírea y marina, química o nuclear-m son también transgresiones a zonas de incompetencia. Unas y otras tienen que ver con cuestiones de desigualdad social, pues no todos los ciudadanos se hallan expuestos ni son por igual vulnerables a sus efectos negativos.

Este último aspecto de la problemática muestra que el cierte en el universo corporativo no consiste tan sólo en el acceso desigual al mismo desde fuera, según la clase, educación y origen social de los candidatos al reclutamiento más las restricciones promocionales y subsiguientes procedentes de sus estructurias jerárquicas internas, sino que consiste también en que la corporación está cerrada a cualquier aspecto de la vida del hombre que no pueda tratar funcionalmente, como problema gerencial y técnico en su esfera de competencia y jurisdicción. Por igual razón, y del mismo modo que cada cultura y sociedad excluye y está cerrada a aqueIlas personas cuyas capacidades son innecesarias o de difícil inserción en su urdimbre, el mundo moderno margina con frecuencia a quienes no satisfacen los requisitos del homo corporativus, en sus diversas variedades y subespecies.

\section{LA SOCIOGENESIS DE LA DESIGUALDAD: LO PERMANENTE Y LO NUEVO}

En escorzo he presentado hasta aquí algunos aspectos de la evolución de la desigualdad moderna. Las consideraciones que siguen intentan sus- 
tanciar y desarrollar algunos problemas que dimanan de mi propio planteamiento.

\subsection{Igualdad, jerarquía y los tres niveles del rango colectivo}

Existen dos regularidades en la dinámica de la desigualdad social que sería conveniente aislar aquí: el proceso de divergencia entre la jerarquía y la igualdad, y el proceso constante hacia la tripartición de la dominación.

a) En toda sociedad compleja existe una marcada tendencia a la divergencia entre jerarquia e igualdad, como proceso continuo. Es decir, hay un desarrollo constante de modos jerárquicos de supraordenación y subordiración, en combinación tensa con la tendencia opuesta, la que lleva a mayor redistribución, nivelación e igualdad en sus diversas formas, las cua. les incluyen la igualdad de oportunidades, la de condiciones materiales y la legal. Como dijo Simmel, el primer proceso es parte de la diferenciación social. En algunos casos obedece a la necesidad de incorporar las personas más cualificadas a las posiciones sociales más necesitadas de ellas de modo que lieven a cabo sus tareas con eficacia. ${ }^{33}$ Esta dimensión funcional del trato recibido segútr sus capacidades objetivas sufre una intensa tergiversación a manos de la clase, la coacción, la discriminación favoritista y la reproducción hereditaria de la desigualdad. Empero, y como explicó Tocqueville, en ciertas sociedades de cariz democrático los rígidos y poderosos frenos contra el igualitarismo que caracterizan a los órdenes atistocráticos no son del todo eficientes. En ellas el proceso doble hacia la formación de jerarquía por un lado, y hacia la igualdad, por otro, es más obvio, y la tensión entre ambas fuerzas, más aguda. Ello no obstante la institucionalización amplia de la redistribución (sin minar la supremacía del privilegio y el acceso limitado popular a posiciones deseables, a través de la educación, la representación política, Ia rutinización de la promoción) puede amortiguar la potencial rebeldía de las clases subordinadas. Tal rebeldía tiene su causa en las lesiones percibidas de la desigualdad en combinación con un igualmente percibido derecho a la accesibilidad a posiciones codiciadas.

Por sí sola, la sociedad ciasista durante el capitalismo competitivo no resolvió el problema de la inestabilidad producido por esta divergencia.

33. El reconocimiento de este aserto de la teoría de Davis-Moore no significa más que una concesión sensata a un aspecto de su concepción de la desigualdad y no contradice una visión discrepante de la suya, en términos de dominacion y conflicto. 
Durante sus fases primerizas y clásicas la privación relativa y la injusticia social fueron sentidas de forma exacerbada. Jamás había sufrido todo el sistema de desigualdad igual deslegitimación. Surgieron así vastos movimien. tos sociales con el ûnico propósito de acabar con él. La valía universal de la ciudadanía y la ideología individualista dieron a muchos esperanzas de avance social que no eran congruentes con las recompensas reales que recibían según sus méritos. ${ }^{34}$ Por ello, no todos aceptaton - ni aceptan hoyla ciudadanía como mera encarnación de detechos humanos: muchos la entendieron también como vía de acceso a las recompensas materiales. Simultáneamente, una «envidia democrática» tocquevilliana empezó a dar un acento sivelador a su concepción de la excelencia humana 0 , más precisamente, a poner en cuestión la excelencia humana como fuente de deferencia y prestigio. Consecuencia parcial de esta deslegitimación múltiple fueron varias tevoluciones que ocurrieron en las primeras fases de la nueva era o bien más tarde en países atrasados en vías de modernización. A pesar de elio el sistema capitalista no sufrió reveses en sus tierras de origen. Como señalé antes ello se debió al creciente excedente económico que ya no podía ser apropiado ni usurpado en su totalidad por la burguesía y sus aliados en detrimento de la mayoría, además de los efectos reforzadores del capitalismo que produjo el también creciente poder adquisitivo del pueblo. Todo ello permitió una corriente de concesiones políticas (como la franquicia electoral), la ređistribución restringida de recursos y la expansión de los servicios públicos, la cual amortiguó a la postre los duros golpes que le asestaba al orden social burgués el proletariado militante y los movimientos revolucionatios.

En contraste con esta situación, la sociedad de clases en la era corporativa subsiguiente está en una posición más favorable para absorber la divergencia entre jerarquia e igualdad. Así, sus instituciones seleccionan y cooptan individuos de todas las clases ( $\mathrm{y}$ en especial de las amplias clases medias) con relativa frecuencia, siempre que sus credenciales sean técnicamente importantes para ellas. Tal incorporación no significa en absoluto promoción social automática, ni tampoco su posibilidad objetiva, pero sí puede significar en muchos casos integración vertical en el sistema de desigualdad, con el consiguiente debilitamiento de los lazos clasistas hori zontales.

Dadas las discrepancias intercorporativas y las aberraciones de algunas

34. «La fuetza de la legitimidad de la estratificación en cualquier sociedad es directamente proporcional al grado de congruencia que existe entre la distribución de recursos primarios y la de distribución de autoevaluaciones (self-evaluations)». L. R. della Fave (1980), p. 962. 
de las corporaciones (tas especializadas en la destrucción bélica o ecológica, por ejemplo), la incorporación de las gentes (ahora definidas como «personal») en cada institución no quiere decir que las tareas que han de realizar sean beneficiosas para la sociedad en general. Pueden ser dañninas para una comunidad, para varias, o para otras sociedades. La incorporación corporativa de números sustanciales de individuos, al reducir la solidaridad de clase, mina la posibilidad de crear coaliciones clasistas para la reforma radical del modo de dominación e imposibilita la destrucción del orden social por este conducto. Por si ello fuera poco la «ocupacionalización» de la clase social significa que ésta tiende a degradarse en mero estilo de vida y de personalidad en las mentes de sus miembros, con lo que sufre una severa despolitización. ${ }^{35}$ En su virtud se entenebrecen las líneas de la desigualdad social clasista y se diluye la conciencia de dominación en una marisma psicológica y cultural. Por otra parte, ese mismo proceso de «ocupacionalización» explica también que algunos sociólogos hayan podido lígar a creer que la ocupación, y no la clase, es ahora la unidad principal de la desigualdad, o a lo sumo que ésta sea una clase constituida en lo esencial por la ocupación y determinada pot la división de las tareas en la era tecnológica. Quizá no se hayan percatado de que la ted ocupacional, a pesar de su inmensa importancia para la creación de la desigualdad, no la agota ni mucho menos, y ciertamente es incapaz de desplazar completamente las causas de la división clasista de la sociedad.

Ello no obstante, cuanto más corporatizada es una sociedad más reacia es su estructura a convertirse en campo para la lid abierta entre clases en el sentido tradicional de enfrentamiento para la eliminación o subyugación total del contrincante. ("Corporatizada» en el sentido pluralista o, mejor, poliárquico, de la palabra. Las sociedades corporativas totalitarias obedecen a una problemática muy diferente en este terreno.) Es esencial para la corporatización de taíz pluralista el reconocimiento de las mutuas autonomías relativas y de la negociación y forcejeo como vía para la distribución de bienes, poder y recursos entre los antagonistas, cuya existencia no se pone en entredicho. De ello se sigue que existe un conservadurismo inherente al sistema: éste no se pone en cuestión, pues él mismo es entendido como medio para la obtención de fines dispares. Las dificultades prácticas que encuentran los grupos extremistas —desde las oposiciones extraparlamentarias a los terroristas - en conseguir una deslegitimación popular de todo el orden social parecen refrendar este aserto. A su vez, no cabe duda que en gran medida estos movimientos responden a las frustraciones y bloqueos producidos por el orden corporativo que se va consolidando, si bien

35. R. Sennet (1974). 
es dudoso que lo amenacen de verdad. Al contrario, crean mayor crispación corporativa y una escalada de las instituciones estatales a interestatales de vigilancia y control del orden social.

b) La neutralización constante del descontento a través de la incorporación institucional y el contrapeso de las lealtades horizontales por medio de las verticales no basta para mantener el modo de dominación en buen funcionamiento. La tácita alianza interclasista entre los estratos más altos y sus subordinados inmediatos - las clases medias- es la que, junto a aquellos fenómenos, consolida tal dominación.

El proceso de tripartición de la desigualdad significa que, en cualquier sociedad compleja, existen tres niveles generales de preeminencia entre los hombres: el dominante, el intermedio y el inferior. Estos tres niveles generales no deben confundirse, analíticamente, con las demás formas o dimensiones de la desigualdad, como son la autotidad, la clase, el privilegio y el poder, si bien existen grados de congruencia con ellos, a pesar de las variaciones que puedan encontrarse en las correlaciones concretas. De la misma manera, los niveles generales de la desigualdad no deben confundirse con los niveles más estrechos, específicos y particulares de la desigualdad que originan los diversos estratos que existen en cada uno de ellos. Los tres niveles generales de preeminencia corresponden a las subdivisiones de la sociedad que se derivan de la corriente de mandos y órdenes. Como expresa lacónicamente Collins, las gentes pueden clasificarse en tres categorías según su lugar en ese proceso: los que dan órdenes, los que las reciben y las dan, y las que sólo las reciben. ${ }^{36}$

Con la aparición de un sistema mundial de interdependencia política, econórnica $y$, en menor grado, cultural, pueden detectarse por to menos tres esferas diferentes en las que tiene lugar la tripartición de la desigualdad: la institucional, la societaria y la transnacional. Las divisiones generales de la desigualdad a triple nivel son muy obvias en las instituciones, sobre todo en las corporaciones cuyos reglamentos las reconocen explícitamente. Es también obvi:a en la división clasista de la sociedad, por muy importantes que sean las cuestiones de composición interna de cada nivel general, así como las de las fronteras entre cada clase o estrato. Es patente también en las relaciones entre centro, semiperiferia y periferia en el sistema económico mundial. ${ }^{37}$

La cohesión general de la sociedad no suele debilitarse por esta subdivisión en tres grandes partes desiguales en poder, bienes y tamaño. Ello

36. R. Collins (1975), p. 63.

37. I. Wallerstein (1979); J. Galtung et al. (1979), pp. 321-324. 
es así porque la subdivisión misma fomenta la consolidación de una alianza - tácita o explícita- entre la parte dominante y la intermedia. De hecho, la división general tripartita de la desigualdad es un aspecto esencial de tal alianza y no es previa a ella ni temporal ni lógicamente. (Así, la ruptura de la alianza «normal» entre las élites de las dos categotías superiores, seguida de realincamientos - por ejemplo, una coalición de descontentos de clase media y obrera--, puede ayudar a precipitar una revolución. Esto parece empíricamente en desacuerdo con la opinión de Marx de que la tripartición social debe desaparecer antes de que la revolución fnal ocurra, a través de una aguda polarización entre proletariado y burguesía. Pero su opinión muestra la importancia que él daba a los poderes moderadores de la pequeña burguesía y a otros estratos intermedios, cuando se alían a la clase dominante, en la dinámica del conflicto de clases.) Estos conceptos son apenas nuevos, ${ }^{38}$ pero los observadores se han mostrado teacios a percibir la división a tres niveles de la desigualdad (y las alianzas de clase que engendra) como una regularidad en la estructura de todas las civilizaciones avanzadas.

Su actitud es comprensible, pues toda concepción de este aspecto de la desiguaidad como si existiera por sí solo, como una mera división aislada en tres categorías, setía una simplificación insostenible. Peto no es así como la tripartición tiene lugar. Aparte de las demás estructuras (institucionales o no) de la desigualdad que la penetran, la tripartición misma se reproduce y halla su eco en muchas esferas de la vida social, y no sólo en la estructura general clasista. Se plasma así, en triparticiones entrectuzadas institucionales, clasistas e internacionales, cada una de ellas dotada de grados diferentes de frmeza y explicitud. Así, el sistema mundial de desigualdad - tan decisivo para la formación de las clases en los confines de cada Estado- es mucho menos estable que ottas subdivisiones a tres niveles. Para complicar las cosas, las compañías multinacionales, con sus modos diferentes de articulación de los sistemas clasistas en cada país en el que operan, más su estructura interna y sus conexiones con la distribución mundial del poder y apropiación de recursos, nos suministran un ejemplo excelente de la complejidad de la situación. Estas corporaciones económicas muestran también cómo las líneas de la tripartición y las coaliciones que ella genera no se funden y desaparecen cuando se examinan de cerca.

38. Iniciada por Platón en su teoría del gobiemo (con la alianza de los guardianes con el rey filósofo) halla desarrollo en la teoria aristotélica de las clases medias y en la marxiana de la pequeña burguesía. 1. Wallerstein (1979) ha sido muy explícito en señalar la función de las alianzas entre los gobiernos del centro y los de la semiperiferia para el mantenimiento del sistema mundial de poder. 


\subsection{La desigualdad y el futuro del conflicto social}

Así pues, las sociedades contemporáneas avanzadas han producido un conjunto de soluciones para habérselas con la doble necesidad de desarroilar jetarquías y de satisfacer el igualitarismo acentuado de la época. A través de la institucionalización de una parte notable de la movilidad ascendente, la relativa "ocupacionalización» de la clase social, y ottos ptocesos, ha tenido lugar una neutralización de los efectos conflictivos que la división clasista tripartita podría generar. Así, los efectos conflictivos de las divisiones de clase han sido amortiguados mediante la multiplicación de tangos ocupacionales y de diferencias salariales y de ingresos. Éstos tienden a crear un espectro de gradaciones que difuye, hace borrosa o hasta invisible la percepción de la clase social como ente antagónico identificable en el con. junto de la sociedad. A esto coadyuva también la aparición de unos estratos de empleados que algunos estudiosos entienden como ejemplo de penetración de la proletarización en el mundo de los setvicios. Sin entrat aquí en la disputada cuestión de la supuesta proletarización de los empleados, lo importante es que aun y cuando sus sueldos sean en muchos casos menores que los del obrero o técnico especializado, el empleado no se ve ni se conduce como proletario. (Que eche mano de recursos otroxa característicos del proletariado, como la huelga, no parece atgumento suficiente: también la usan ya los mismos profesionales «liberales» en casos señalados.)

Estas soluciones a la contradicción principal de la desigualdad no son estáticas. Son reelaboradas constantemente por unos procesos de negociación del reequilibrio entre las diversas corporaciones en liza para el reparto de los recursos y las tareas. Sus élites respectivas se mueven en un universo en el cual el poder ya no es concebido en términos de suma ceto $(\mathrm{P}=\Sigma 0)$ a causa del triunfo de la ideología pluralista. (A esta ideología puede corresponder perfectamente un mundo objetivo pseudopluralista, poliárquico, y con zonas oligopolistas y otras monopolistas.)

Mientras tanto mucho's rasgos del pasado reciente continúan conformando la vida de la sociedad emergente. Durante la segunda guerra mundial algunos anunciaron el fin de la civilización decimonónica, pero varios decenios más tarde ottos críticos aseguraban que continuaba estando con nosotros. ${ }^{39} \mathrm{La}$ verdad parece ser que algunos de los rasgos principales de la edad de la ascendencia burguesa están muy lejos de ser reliquias. Mediatizadas y mediatizadoras de nuevas instituciones, en tensión con lo

39. «La civilizacion del siglo $\mathrm{xIX}$ se ha hundido»: Las primeras palabras de Polanyi en su Gran Transformación (1944), p. 3. «El siglo xIX no ha acabado», R. Sennet (1977), p. 27. 
nuevo, continúan determinando nuestro mundo. Algunas de ellas parecen empezar a ser tecesivas, confrontadas por fuerzas para las que no estaban preparadas. Éste es el caso especial de ese complejo moral y cultural al que llamamos individualismo. Por su parte, el mercado se ha hecho oligopolista y sufre más que nunca de fuerzas extraeconómicas, si bien el paso del precio determinado por el mercado al precio puramente político no ha ocurrido del todo. Por todo ello, sexía prematuro afirmar una vueita a la primacía incontestada de lo político sobre lo económico, en los aspectos cruciales de la vida moderna. De igual modo, el componente legal-racional del sistema jurídico y constitucional de nuestras politeyas todavía pesa mucho, a pesar del incesante crecimiento de la esfera legal reguladora, prescriptiva y ligada a una concepción administrativa de la vida social. No obstante, hasta cuando se toman debidamente en consideración esta y otras cualificaciones parecidas sobre las continuidades históricas que pueden percibirse en medio de tanta mudanza e inestabilidad parece clato que el orden social que se perfila comienza ya a diferir sustancialmente de la situación que le precedió.

Hacet hincapié, como lo he hecho hasta aquí, sobre las fuerzas de equilibrio de la nueva estructura de la desigualdad social no significa que la haya aceptado como estable. De la misma manera, el entendimiento del orden capitalista burgués de antaño como estadio transitivo entre otros dos no entraña una visión de estos dos últimos como más importantes que él. Todos los períodos son transitivos, pero algunos poseen características duraderas muy acusadas. Así, sabemos que aunque la mudanza social fue muy intensa durante la era medieval, sus notables continuidades politicas, religiosas y económicas nos permiten tratar aquel largo y violento período como un único universo histórico. A pesar de las intensas fuerzas innovadoras de nuestro mundo, existe la posibilidad de que la sociedad que ahora empieza a surgit posea durante mucho tiempo ciertos rasgos básicos y duraderos, por muy sujeto que esté a las tensiones, fricciones y enfrentamientos que producen sus propias contradicciones. Sobresaldrán entre estas últimas las creadas por la desigualdad social y, en especial, por las formas nuevas de desigualdad que son especfficas de la sociedad que alborea. Señalaré algunas de eilas.

a) La historia futura de la desigualdad presenciatá, con toda probabili$\mathrm{dad}$, una continuación de la contradicción esencial de la desigualdad en la era contemporánea. Como he indicado más artiba, ésta dimana de la necesidad de satisfacer los imperativos de la jerarquización producidos por las instituciones de la economía, dei Estado y de las burocracias, al tiempo que deben satisfacerse las exigencias de la deslegitimación de la desigualdad generadas 
por la cultura política occidental. (Podría argüirse que la ideología soviética ha restzelto este dilema mediante una glorificación simultánea de la desigualdad y de los rangos oficiales, que se «explican» sistemáticamente en su nombre. Pero ello es dudoso, pues hay indicaciones de que la ideología es vista como tal, y no como cultura interiorizada, pot parte del pueblo. Ello puede ser fatal, a largo plazo, para la permanencia de la fórmula monopolista del corporatismo soviético y no digamos para la clase tecnoburocrática dominante.) A falta de la aparición de una religión universal u otto medio semejante para la justif́cación de la desigualdad, los gobiernos occidentales deberán continuar confiando en la redistribución de cantidades satisfactorias de bienes y servicios para eliminar amenazas serias de contestación radical masiva contra el orden en el que se basan. Sin desđeñar el peso de la creencia ciudadana en los valores del sistema constitucional y legal-racional de derecho, no es posible pensar que él por sí solo pueda sostener dicho orden. La pura represión estatal podría constituir una alternativa, efímera por fortuna, pero en todo caso fatal para la sobrevivencia del universo liberal.

b) Ha quedado claro cómo la economía (con su tasa de crecimiento decreciente) combinada con la congestión que proviene del acceso popular a bienes escasos (carreteras, edificios, escuelas, hospitales, montes, parques, subsidios estatales) sólo puede crear una intensificación de la biperregula. ción, y, por lo tanto, la burocratización. (EI advenimiento de la burocracia tecnológica a través de la revolución microelectrónica «desburocratiza» la burocracia misma, pero no sus efectos sobre la ciudadanía, pues posibilita una inflación de reglamentos administrativos de control de la vida cotidiana. Así, el aligeramiento de las transacciones documentales («papeleo») no entraña un aligeramiento correspondiente en las obligaciones públicas de los ciudadanos.) Otras tendencias refuerzan esta corriente. Descuella entre ellas la militarización continua y la atribución de recursos gigantescos al armamento y al mantenimiento de los grandes ejércitos modernos.

$\mathrm{El}$ asunto desde la perspectiva de este análisis es que, en ausencia de frenos percibibles, estas tendencias son, todas ellas, jerarquizantes. Todas ellas intensifican la «ocupacionalización de todo el mundo» en corporaciones con aguda diferenciación funcional interna y criterios de demarcación subordinada para sa personal. Tales corporaciones requieren la multiplicación de restricciones regulatorias para personas que, en principio, tienen derecho a mayor libertad que la que gozan. En la sociedad corporativa los criterios posicionales prevalecen sobre los contractuales, o libremente crea* dos por las partes. En la liberal las relaciones son en teoría (y en la práctica pata ciertas categorias privilegiadas) fruto de decisiones mutuas entre 
personas que deben hacer honor a ellas, una vez concluido el acuerdo. En la sociedad corporativa las obligaciones y transacciones manan más clatav mente de las posiciones que las personas ocupan en Ias instituciones, aunque hayan entrado en ellas originalmente según los criterios contractuales o pseudocontractuales del mercado de trabajo.

La expansión del universo regulatorio no ocurre solamente en virtud de las exigencias internas de las corporaciones. La atticulación mutua de intereses y los acuerdos entre corporaciones cuentan también. Otro factor es el Estado, cuyas tareas en establecer criterios societarios de prioridades, demarcación y subordinación son bien patentes. Su modo de intervención difiere sustancialmente del étatisme de antaño, cuando lo hacía como complemento natural a los intereses de la burguesia, o pata arbitrat entre sus diversos sectores de las clases dominantes. El étatisme de hoy es más difuso y menos claramente ligado a una clase concreta. (Menos ligado a la clase, esto es, en el sentido tradicional, pues el auge del componente tecrocrático del Estado a través de una burguesía estatal o de clase tecnoburocrática indica nuevas tendencias en la formación de clase. $\mathrm{Y}$ no se olvide el predominio de las clases medias en el aparato estatal, por ellas colonizado preferentemente.) La paradoja, antes apuntada, es que en conjunción con la internacionalización de las relaciones y el ascenso de entidades políticas y económicas supraestatales el Estado sobetano aislado entrará en crisis, al tiempo que el intervencionismo y la intermediación estatal en la vida social continuarán creciendo. De no cambiar las cosas la mediación e intermediación supranacional y local administrativa continuatán en expansión.

c) En la historia de los movimientos sociales en lucha por mayor igualdad se ha producido un paso de lo universal a lo comunitario. Los primeros movimientos quizás ocultaran su clasismo y egoísmo colectivo tras pretensiones universalistas, pero en el proceso de alcanzar sus objetivos se veían obligados a incorporarlos en cartas de derechos generales, declaraciones universales y gatantías constitucionales a todos aplicables. En contraste con ellos, las minorías raciales o cuiturales, las mujeres, los minusválidos, los parados --por muy justificados que se hallen en su lucha por la emancipación y la igualdad- suelen hacer énfasis en su existencia como comunidades únicas, distintas y específicas. En muchos casos exigen discriminación positiva, o «trato de favor», como único camino para su emancipación. Esa emancipación implica a menudo una afirmación de su detecho a ser diferentes, y ello nos retrotrae a la cuestión de si en última instancia es posible ta igualdad en un mundo de comunidades distintas, si es cierto que la diferenciación social inevitablemente genera desigualdad. En 
todo caso, es interesante: notar que las declaraciones de solidaridad de algunos de estos grupos 0 comunidades con las clases subordinadas no son muy frecuentes. Cuando ocurre suelen quedarse en lo retórico, con algunas excepciones. Raras también son sus coaliciones entre sí o con otras colectividades que sufran discriminación metamente clasista. La fragmentación de la oposición radical en colección de minorías con sus agravios específicos puede entrañar que las aspiraciones universalistas del liberalismo radical antiguo y del socialismo revolucionatio sufran menoscabo. La cosa apunta hacia una «retribalización» incipiente y hacia un provincialismo de grupo de interés. Ambas formas de desigualdad son imprevistas en las sociedades industriales avanzadas. Cabría concebir la discriminación generada por los movimientos antidiscriminatorios, quizá como un subproducto pasajero de una transición a formas supetiores de emancipación genetal, pero ello implicaría hacer predicciones considerables. En todo caso debe notarse.

d) La utopia meritocrática es imposible. Ello no se debe sólo a la revuelta hipotética de los subordinados contra los meritócratas en un distante porvenir ${ }^{40}$ sino, y con menos dramatismo, a la presencia continuada de los modos tradicionales de cierre y reproducción clasista en las sociedades contemporáneas avanzadas. El cierre tradicional de clase impide, entre otros factores, la pérdida por movilidad ascendente para las clases subordinadas de sus individuos más capaces. (Paradójicamente la utopía meritocrática propone el advenimiento de una sociedad con escisiones de clase mayores que las de la nuestra, pues en ella todo talento se draga hacia artiba, empobreciendo en habilidad e inteligencia a los estratos inferiores.) Los efectos «positivos» del mantenimiento de un grado mínimo de cierre que fomente la calidad de la base intelectual y genética de las clases subordinadas no debe ignorarse por mucho que pueda prestarse a una interpretación antidernocrática. La desigualdad social implica siempre injusticia y ésta no merece excusa alguna. Si de ella se derivan algunos efectos indirectos beneficiosos, éstos sólo pueden set entendidos como subproducto inesperado y muy secundario de una situación esencialmente indeseable.

La imposibilidad de un sistema meritocrático consistente no se basa tan sólo en los duros hechos del cierre clasista. También estriba en la cuestión no resuelta de saber quiś constituye mérito. A menos que surja un sistema de valores relativamente homogéneo para la identificación pública de la excelencia humana y cle las necesidades sociales prioritarias no será posible establecer la meritocracia sobre bases frmes. Lo que hoy ocurre es que poseemos criterios plurales de mérito, según las áreas en que se re-

40. M. Young (1962). 
conozca. Así, el carisma institucional de los sacerdotes y jerarquías eclesiales deriva de fuentes tradicionales conocidas. La autoridad técnicamente experta justifica su preeminencia en su capacidad de introducir cambios o remedios beneffciosos en nuestra vida, y de índole práctica. Privados de sanción transcendental, los políticos son definidos como excelentes -aunque ello no sea así para sus enemigos- por su capacidad de convocatoria electoral y su éxito en la liza por la popularidad. No existe, pues, ningún sistema unitario para la identificación de la excelencia humana. Las sociedades occidentales están confusas en cuanto a qué es lo que constituye excelencia como base para la desigualdad y distribución de estatus. No obstante, en vittud de la expansión de las jerarquías de mérito a los campos más diversos de actividad, han conseguido premiar a una gran diversidad de individuos de modo que no entren en competición directa entre sí, mediante Ia especialización y diversificación de los canales de estatus. El deporte, los espectáculos, el ejército, la industria, los sindicatos, se han convertido en vías de acceso a la promoción para el talento y la habilidad en cualquier clase, pero en especial en las subordinadas, mientras que las superiores han conservado sus antiguos cotos.

La excelencia bumana no se decide ya solamente mediante los criterios culturales de las clases dominantes, ni mediante los de una poderosa y compleja religión. Se decide también mediante el consenso negociado y a través de comités de premios y tribunales de nombramiento y atribución. En ciertos casos tal excelencia se consolida mediante la celebridad conseguida por algunos entre su público respectivo. Cada esfera de privilegio y excelencia atribuye sus propios honores y promueve a sus propias figuras según sus criterios y reglas distintos. Por lo tanto, la autoridad basada en el mérito ha sufrido una severa fragmentación en el caso de actividades especializadas. En aquellas que exigen la creación de figuras públicas, el «estrellato» -en política, arte, religión-w ha venido a servir como justificante del privilegio y la autoridad.

No obstante, como en tiempos pasados, cuanto menos poderosa es una élite (cuanto menos estratégica es) más accesible tsuele ser a los miembros capaces de las clases inferiores. Esto aún da coherencia al sistema de clases y propósito a las élites poderosas. Además, la nueva proliferación de élites populares (no estratégicas), en vez de constituir un teto al dominio de las podetosas las deja en paz. Existe hoy una vasta zona en la que una mentocracia domesticada y contenta, sin poder real, puede medrar. El campeón deportivo, el soldado, el sindicalista, el astronauta, el poeta, el predicador son reconocidos como héroes sólo por sus seguidores y sus públicos, que pueden llegar a ser muy vastos pero que no determinan la distribución social del poder. Su reconocimiento oficial por gobiernos y «fuerzas vivas» 
refrenda la multiplicidad de criterios para el mérito, pero es irrelevante para la estructura real de la dominación.

e) Esta cuestión de la metitocracia y la tecnocracia como base para la estructuración de la desigualdad nos lleva a la de la clase dominante en la sociedad corporativa. Bajo condiciones de corpotatismo intenso su análisis se hace dif́cicil, y se comprende la tentación de abandonarlo con el pretexto de que la noción misma de clase dominante pertenece a tiempos pasados. Si aceptamos la existencia de una multiplicidad creciente de élites y la de pirámides de poder e influencia que se interpenetran podríamos argüir que tal clase ya no existe, por lo menos en su formulación clásica. A lo sumo, ditían algunos, poseemos una red de élites interdependientes, ampliamente reclutadas en algunos casos, y que se encuentran en estado de negociación permanente entre sí. No es sólo una negociación sobre bienes y servicios sino que lo es en torno a su propio poder y prerrogativas. Sin embargo continuamos teniendo pruebas abundantes a favor de la hipótesis de la clase dominante: la reproducción clasista continúa siendo intensa; la acumulación ptivada de riqueza en manos de un porcentaje reducido de ciudadanos no ha disminuido. La «clase política» profesional en cada país casi siempre fomenta o protege los intereses de las clases dominantes; las íntimas relaciones de los altos funcionatios -la criptoburocracia, para usar la expresión de Weber-y el alto estamento militar con las clases altas son patentes.

Todo esto no es contrario a la estructura de una sociedad corporativa. Tal sociedad fue definida desde el primer momento como sociedad de clases. Es una sociedad clasista que ha redefinido sus términos de referencia. Así, existen buenas razones para rechazar la concepción simplista de la desigualdad contemporánea como si dependiera de una conspiración de «complejo militar-industrial» contra el pueblo. $\mathrm{Y}$ también las hay para aceptar el hecho de que al ascenso de muchas jerarquías plurales, vinculadas de modo diferente a cada clase social, no impide la formación paralela de una red de élites pode:osas. Éstas, a su vez, están vinculadas a las clases medias y altas, aunque la dinámica de la situación les obligue a acomodarse y adaptarse tmás que en otros tiempos a los recién llegados: la nuestra ha sido la época de la educación igualitaria de los poderosos. Durante el siglo XIX los políticos influyentes, los grandes capitanes de industria, los generales, financieros, ideólogos respetables no procedían siempre de las clases altas. En el xx tampoco proceden de ellas necesariamente los tecnó cratas, los consejeros políticos y económicos, los presidentes del gobietno, los científicos, ingenieros y personajes célebres. Su entrada en el reino de la autoridad, el poder y el privilegio ha surgido de la indispensabilidad 
de las corporaciones a las que pertenecen o que representan: elias son sus plataformas de lanzamiento, son también las instituciones sociales que han redefinido la naturaleza de la desigualdad de clase y reorientado su conflicto.

He dicho que la sociedad corporativa era hostil a la lucha de clases. Ello es cierto en la medida en que ha incorporado a las clases subordinadas en sus múltiples redes ocupacionales verticales, en combinación con su capacidad de apaciguar, desviar y sublimar el descontento de los parados, de los pobres y de los radicales. Es por lo tanto una sociedad muy favorable a la clase, aunque su tratamiento de ella no tenga precedentes: la cuida de un modo que nadie había previsto, salvo en la elucubración de algún petasador utópico. Las funciones tutelares de las instituciones públicas mantienen a los necesitados en su lugar. Los subsidios gubernamentales, sus servicios sociales y la dinámica ocupacional de la economía confina a obreros y empleados a sus tutinas y espacios sociales. Estos y otros procesos de reequilibtio han conseguido dotar a la sociedad contemporánea de una notable capacidad de adaptación a los problemas que crean sus propias antinomias en el campo de la dominación y la desigualdad. Tan es así que si existieran por sí solos cabría suponer la permanencia y solidez de las estructuras que sobre ellos se apoyan. La cuestión, sin embargo, parece ser que tales procesos de reequilibrio y absorción social se basan a su vez en la existencia de otro haz de procesos paralelos, cuya continua expansión sólo puede conducir a una crisis muy seria del orden corporativo en que se apoyan, por pura desmesura. Cuéntanse entre estos últimos la desordenada hiperproducción de bienes innecesarios, la sobreexplotación de recursos escasos, el desatado crecimiento demográfico, la acumulación del arsenal bélico nuclear y tecnológico.

\section{A MODO DE CONCLUSION}

La gravedad de estas últimas corrientes, que parecen hoy desenfrenadas, no debe empequeñecer la urgencia e importancia de los problemas que dimanan de la desigualdad y de la dominación sociales. De hecho, son el modo de dominación y la forma de la desigualdad los que en gran manera los causan.

Es injustificable aplazar la solución de la injusticia de clase, del privilegio y el poder sin autoridad con la excusa de que los otros problemas son más apremiantes, pues está clato que los últimos son en muy gran medida consecuencia de los primeros. Menos justificable es abrazar el neo- 
conservadurismo pseudocientífico de sociobiólogos, economistas antiigualitaristas y de pesimistas filosóficos para argumentar en favor de la desigualdad injusta." Lo que parece perentorio en cambio es mantener el énfasis sobre las dificultades estructurales reales que balla la sociedad moderna para evolucionar hacia un universo tan libre como igual.

Las reflexiones anteriores se insertan en la tradición sociológica que se preocupa por esta cuestión. Se han confinado al surgimiento de una sociedad relativamente corporatizada en el seno de las sociedades butguesas pluralistas occidentales (dejando al margen la aparición de sociedades corporativas tecnoburoctáticas con control monolítico de la desigualdad, como es el caso de la Unión Soviética) y han intentado integrat el análisis clasista con el institucional. Con ello he intentado mostrar que son las distorsiones del poder en la naciente era corporativa las que engendran sus peligros más obvios y las que, oscuramente, más amenazan nuestro común porvenit.

41. P. Green (1981). 


\section{BIBLIOGRAFIA}

Aylmer, G. E. «Bureaucracy» in P. Burke (ed.). The New Cambridge Modern History, vol. XIII (Companion Volume), Cambridge University Press, pp. 164-200, 1979.

David, K., and Moore, W. E. "Some Principles of Stratiffcation" in R. Bendix, and Lipset, S. M. Class, Status and Power, Free Press, pp. 47-53. New York, 1966.

Drucker, P. The Age of Discontinuity, Harper and Row, New York, 1968.

Elias, N. The Civilizing Process: The History of Manners, Unizen Books, New York, 1978.

Fave, L. R, della. "The Meek shall not Inherit the Earth: Self-evaluation and the legitimacy of stratification", American Sociological Review, vol. 45, núm. 6, pp. 955-971, diciembre 1980 .

Fohlen, C. Qu'est-ce que la revolution industrielle?, Robert Laffont, Patís, 1971.

Giner, S. Mass Society, Martin Robertson, London, 1976.

Giner, S. «La agonía de la sociedad civil» in Leviatán, núm. 5, pp. 87-96, 1981.

Giner, S, a) «The Political Economy of Southern Europe», British Journal of Sociology, junio 1982, pp. 172-199, vol. 33, núm. 2.

Giner, S. b) «La conquista del caos» in F. Reinares (ed.), Terrorismo y sociedad democrática, Madrid, Akal, 1982.

Giner, S., and Pérez-Yruela, M. La sociedad corporativa, Madrid, CIS, 1979.

Green, P. The Pursuit of Inequality, Oxford, Martin Robertson, 1981.

Habermas, J. Tecbnik und Wiesenschaft als Ideologie, Frankfurt, Suhrkampf, 1968.

Habermas, J. Legitimationsprobleme der Spätkapitalismus, Frankfurt, Suhrkampf, 1973.

Hewitt, C. The Effect of Political Democracy and Social Democracy on Equality in Industrial Societies: «A Cross-National Comparison» in American Sociological Review, vol. 42, núm. 3, pp. 450-463 (1977). Jessop, B. Corporatism, Parliamentarism and Social Democracy, in P. C. 
Clase, poder y privilegio en la sociedad corporativa

Schmitter and G. Lehmbruch (eds.), Trends Towards Corporatist Intermediation, Sage (1979).

Kolko, G. Wealth and Power in America: an Analysis of Social Class and Income Distribution, Praeger, New York, 1962.

International Research Group. Industrial Democracy in Etsrope, Oxford University Press, 1981

La Palombara, J. Clientela o parentela: studio sui gruppi d'interese in Italia. Milan: Comunità (Interest groups in Italian Politics), Princeton University Press, Princeton, N. J., 1964 (1967).

Laqueur, W. Europe since Hitler, London, Weldenfeld and Nicolson, 1970.

Lenski, G. Power and Privilege, a Theory of Social Stratification, New York, McGraw Hill, 1966.

Linz, J. J. A century of politics and interests in Spain, en S. Berger (ed.), Organizing Interests in Western Europa, Cambridge, 1981, pp. $367-$ 415 .

Lipset, S. M., and Zeterberg, H. L. Social Mobility in Industrial Societies, in S. M. Lipset and R. Bendix, Social Mobility in Industrial Society, Berkeley: University of Californa Press, Ch. 2.

Malefakis, E. Peasants, Politics and Civil War in Spain, 1931-1939, in Bezucha, R. J. (Ed.), Modern European Social History, Lexington, Mass.; Heath and Co., pp. 192-227 (1972).

Marshall, T. H. Citizensbip and Social Class, Cambridge University Press (1950).

Moyano, E. El corporatisino en la agricultura: el caso de España, Tesis doctoral, Universidad de Córdoba, 1982.

Panitch, L. «Recent Theorisations of Corporatism», Britisb Journal of Sociology, núm. XXXI, núm. 2 (1980).

Pareto, V. Trattato di Sociologia Generale, Florence (Ist. end, 1916) (1923).

Pareto, V. The Mind and Society: A Treatise on General Sociology, New York, Dover (1963).

Perkin, H. The Origins of Modern English Society 1780-1880, E. Routledge and Kegan Paul., London, 1969.

Petrot, M. The Three ages of Industrial Discipline in Nineteenth-Century France, in Merriman, J. M. (ed.), Consciousness and Class Experience in Nineteentb Century Europe, Holmes and Meier, pp. 149-163, New York, 1979.

Rostow, W. W. The World Economy: History and Prospect, The University of Texas Press, Austin, 1978.

Rubinson, R. «The World Economy and the Distribution of Income within States: a Cross-National Study», in American Sociological Review, vol. 41 (Aug.), pp. 638-659 (1976).

Schmitter, P. "Still the Century of Corporatism?», Review of Politics, núm. 36, January (1977).

Schumpeter, J. A. Business Cycles, New York, McGraw Hill, 1939. 
«Papers»: Revista de Sociologia

Schumpeter, J. A. Imperialism and Social Classes, New York, Augustus Kelley, 1961.

Sheehan, J. H. Conflict and Cobesion Among German Elites in the Nine. teentb Century, in Bezucha, R. J. (ed.), Modern European Social History, Mass.: D. C. Health and Co., pp. 3-27, Lexington, 1972.

Shonfield, A. Modern Capitalism: The Changing Balance of Public and Private Power. Oxford University Press, London (1965).

Strasser, H. «Stratum and Class Formation: principles of a theory of social inequality», in Canadian Journal og Sociology, vol. 5, núm. 2, pp. 102$120(1980)$.

Therborn, G. «The Role of Capital and the Rise of Democracy», New Left Review, núm. 103.

Tilly, C. The Formation of National States in Western Europe, Princeton University Press (1975).

Tilly, C. Did the Cake of Custom Break?, in J. M. Mertiman, Consciousness and Class Experience in Nineteenth.Century Europe, Holmes and Meier, pp. 17-39, New York, 1979.

Unger, R. M. Law in Modern Society: Toward a Criticism of Social Tbeory, New York, Free Press, 1976.

Veyne, Paul, Le Pain et le cirque, París, 1976.

Weber, E. Peasants into Frencbmen: Tbe Modernization of Rural France, 1870-1914. Stanford University Press (1976).

Young, M. The Rise of the Meritocracy, 1870-2033, Hardmondsworth, Penguin (Ist. end. 1958) (1962). 